Pesq. Vet. Bras. 29(9):753-766, setembro 2009

\title{
Intoxicação experimental aguda por samambaia (Pteridium aquilinum) em bovinos ${ }^{1}$
}

\author{
Bruno L. Anjos², Luiz F. Irigoyen³ ${ }^{3}$, José Vitor M. Piazer ${ }^{4}$, Juliana S. Brum5, \\ Rafael A. Fighera ${ }^{3}$ e Claudio S.L. Barros ${ }^{3 *}$
}

\begin{abstract}
Anjos B.L., Irigoyen L.F., Piazer J.V.M., Brum J.S., Fighera R.A. \& Barros C.S.L. 2009. [Experimental acute poisoning by bracken fern (Pteridium aquilinum) in cattle.] Intoxicação experimental aguda por samambaia (Pteridium aquilinum) em bovinos. Pesquisa Veterinária Brasileira 29(9):753-766. Departamento de Patologia, Universidade Federal de Santa Maria, Camobi, Santa Maria, RS 97105-900, Brazil. Email: claudioslbarros@uol.com.br

This experiment was design to address the following points in relation to the acute poisoning by bracken fern (Pteridium aquilinum) in cattle: 1) the severity of the thrombocytopenia in different stages of the intoxication and its relationship to possible deficits in the secondary hemostasis, 2) the relationship between neutropenia and the morphological signs of septicemia occasionally found at necropsy, and 3) the mechanism of anemia and its relationship with blood loss, medium life of erythrocytes and the progress of the disease. The fresh green upper parts of $P$. aquilinum were fed to four mixed breed calves with average age of 18 months and weights ranging from 190 to $215 \mathrm{~kg}$. A calf of similar age and weight was kept together with the other four under the same conditions, except for the ingestion of $P$. aquilinum. The four fern-fed calves died with typical features of acute bracken fern poisoning after being fed with the plant for 53-58 days daily doses of $8.0,8.6,10.2$, and $10.6 \mathrm{~g} / \mathrm{kg}$ body weight totaling at the end of the experiment, respectively, $59.3 \%, 63.3 \%, 47.4 \%$, and $47.5 \%$ of bracken fern in relation to their body weight. The disease was characterized by fever up to $42.5^{\circ} \mathrm{C}$ and varying degrees of hemorrhages observed clinically, at necropsy and on histological examination. Death occurred 6-7 days after the onset of fever. The hematological changes consisted mainly of marked thrombocytopenia and neutropenia. Two of the four affected calves had mild anemia. The deficits in secondary hemostasis were mild in each case. There were no significant changes thus permitting to rule out the role of secondary hemostasis in the pathogenesis of the hemorrhages in the bracken fern poisoning. The measurement of fibrin degradation products in the serum showed conflicting results and did no allow for a solid conclusion regarding the role of disseminated intravascular coagulation in the pathogenesis of the hemorrhages in fern poisoning. The cytology and the histopathology of bone marrow from the four poisoned calves revealed marked decrease in the numbers of hematopoietic cells from the three marrow lineages, which characterizes marrow failure due to aplasia; it was concluded that the events of the primary hemostasis due to thrombocytopenia are responsible for the hemorrhages. In blood culture from three affected
\end{abstract}

\footnotetext{
${ }^{1}$ Recebido em 15 de dezembro de 2008.

Aceito para publicação em 2 de junho de 2009.

Parte da Dissertação de Mestrado do primeiro autor. Financiado integralmente pelo Grant de Pesquisador I-A do CNPq (Proc.307876/2006-3).

2 Programa de Pós-Graduação em Medicina Veterinária, Área de Concentração em Patologia Veterinária, Centro de Ciências Rurais (CCR), Universidade Federal de Santa Maria (UFSM), Camobi, Santa Maria, RS 97105-900, Brasil.
}

\footnotetext{
${ }^{3}$ Departamento de Patologia, Centro de Ciências da Saúde, UFSM, Avenida Roraima 1000, Cidade Universitária, Santa Maria, RS. *Pesquisador I-A do CNPq (Proc.307876/2006-3) e autor para correspondência: claudioslbarros@uol.com.br

${ }^{4}$ Inspetoria Veterinária de Jaguari, Rua Carlos Calegaro 290, Jaguari, RS 97760-000, Brasil.

${ }^{5}$ Bolsista de iniciação científica do CNPq junto ao Departamento de Patologia da UFSM, Santa Maria, RS.
} 
calves there was growth of Klebsiella oxytoca, Staphylococcus hyicus and Staphylococcus aureus, indicating that septicemia, facilitated by neutropenia could have a role in the death of cattle acutely poisoned due to the ingestion of $P$. aquilinum. Additional points of the interest in the acute experimental poisoning by bracken fern in cattle reported here were the development of hematuria and the so called laryngeal form.

INDEX TERMS: Diseases of cattle, poisonous plants, bracken fern, Pteridium aquilinum, disturbs of hemostasis, bone marrow aplasia, pathology.

RESUMO.- Este experimento foi delineado para investigar os seguintes pontos em relação à intoxicação aguda por samambaia (Pteridium aquilinum) em bovinos: 1) a intensidade da trombocitopenia em diferentes momentos da intoxicação e sua relação com possíveis déficits na hemostasia secundária, 2) a relação da neutropenia com as manifestações morfológicas de septicemia ocasionalmente observadas na necropsia, e 3) o mecanismo da anemia e sua relação com a perda de sangue, a vida média eritróide e a evolução da doença. As hastes superiores mais verdes de $P$. aquilinum foram administradas a quatro bovinos sem raça definida, com idade média de 1,5 ano e pesos entre $190-215 \mathrm{~kg}$. Um bovino de idade e peso semelhantes foi usado como controle e, exceto por não ter recebido $P$. aquilinum, foi mantido nas mesmas condições que os outros quatro. Os quatro bovinos que receberam a planta morreram com quadro característico da intoxicação aguda por samambaia após receberem durante 53-58 dias, doses diárias de 8,0, 8,6, 10,2 e 10,6g/ $\mathrm{kg}$ de peso corporal, que totalizaram, ao final do experimento, respectivamente, $112,7,107,6,85,7,90,15 \mathrm{~kg}$ da planta, o que corresponde, respectivamente, a $59,3 \%$, $63,3 \%, 47,4 \%, 47,5 \%$ da planta em relação ao peso dos bovinos. A doença caracterizou-se por febre de até $42,5^{\circ} \mathrm{C}$ e diversos graus de hemorragias observadas clinicamente, na necropsia e na histopatologia. A morte ocorria 6-7 dias após o início do quadro febril. As alterações hematológicas revelaram trombocitopenia e neutropenia acentuadas. Em dois dos quatro bovinos havia anemia leve. Não houve variações significativas nos tempos de coagulação dos bovinos intoxicados, quando avaliados os fatores de coagulação (secundária), excluindo-se assim a possibilidade da participação de distúrbios da hemostasia secundária na patogênese das hemorragias nessa intoxicação. A determinação dos produtos da degradação da fibrina no soro revelou dados conflitantes, não permitindo concluir se a coagulação intravascular disseminada tem participação na patogênese das hemorragias nessa intoxicação. A citopatologia e histopatologia da medula óssea dos quatro bovinos intoxicados revelaram acentuada diminuição no número de células hematopoéticas das três linhagens medulares, caracterizando insuficiência medular por aplasia; conclui-se que apenas eventos da hemostasia primária devidos a trombocitopenia são responsáveis pelas hemorragias. Na hemocultura de três dos bovinos intoxicados houve crescimento de Klebsiella oxytoca, Staphylococcus hyicus e Staphylococcus aureus, indicando que a septicemia, facilitada pela neutropenia, pode ter participação na causa da morte de bovinos na intoxicação aguda pela ingestão de $P$. aquilinum. Aspectos adicionais de interesse na reprodução da intoxicação aguda por samambaia em bovinos deste relato incluem o desenvolvimento de hematúria na doença aguda e a apresentação da chamada forma laríngea da doença.

TERMOS DE INDEXAÇÃO: Doenças de bovinos, plantas tóxicas, samambaia, Pteridium aquilinum, distúrbios da hemostasia, aplasia de medula óssea, patologia.

\section{INTRODUÇÃO}

A intoxicação por samambaia (Pteridium aquilinum) é a segunda causa mais importante de intoxicação por plantas na Região Central do Rio Grande do Sul, correspondendo a $12 \%$ de todas as mortes causadas por plantas tóxicas em bovinos (Rissi et al. 2007). A doença em bovinos manifesta-se sob três formas: duas crônicas, caracterizadas por neoplasmas no trato digestivo superior e na bexiga (Tokarnia et al. 1969, Souto et al. 2006a,b), e uma aguda, caracterizada por hemorragias (Tokarnia et al. 1967, Anjos et al. 2008).

Os aspectos históricos, epidemiológicos, laboratoriais, clínicos, patogênicos e patológicos da doença hemorrágica induzida pela ingestão de samambaia em bovinos foram recentemente revisados (Anjos et al. 2008). Os achados clínicos, hematológicos e patológicos observados naquele trabalho indicavam que um estudo sistemático para esclarecer vários pontos da intoxicação aguda por $P$. aquilinum em bovinos era necessário.

O experimento aqui descrito foi então delineado para esclarecer os seguintes aspectos da intoxicação aguda por samambaia em bovinos: 1) a intensidade da trombocitopenia em diferentes momentos da intoxicação e sua relação com possíveis déficits na hemostasia secundária, 2) a relação da neutropenia com os infartos sépticos ocasionalmente observados na necropsia, e 3) o mecanismo da anemia e sua relação com a perda de sangue, a vida média eritróide e a evolução da doença.

\section{MATERIAL E MÉTODOS}

Animais do experimento. Foram utilizados cinco bovinos (Bov.1-5), machos, sem raça definida, com média de idade de 18 meses e pesos entre $190-225 \mathrm{~kg}$. Os bovinos foram everminados e mantidos em baias individuais por duas semanas antes do início do experimento para adaptação às instalações e a alimentação. Diariamente, as baias eram limpas e os animais avaliados quanto ao estado geral, o apetite, a coloração das mucosas, a temperatura retal, os movimentos respiratórios, a freqüência cardíaca, os movimentos ruminais e o aspecto da urina e das fezes. 
Local do experimento, colheita da planta, doses e métodos de administração. A primeira colheita da planta e o início do experimento foram em 5 de novembro de 2007. O local onde a planta era colhida pertence ao município de Jaguari, RS, encontra-se a uma altitude de $381 \mathrm{~m}$ e tem precipitação anual de $1.477,7 \mathrm{~mm}$ com temperaturas que variaram no ano de 2007 de $8-33^{\circ} \mathrm{C}$. O solo do local tem $\mathrm{pH}$ ácido $(4,5)$, propício para o desenvolvimento de Pteridium aquilinum. As hastes superiores mais verdes da planta eram colhidas diariamente nas primeiras horas da manhã, trituradas e fornecidas no cocho misturadas a capim e feno de azevém (Lolium multiflorum) e capim-papuã (Brachiaria plantaginea) na proporção capim:samambaia de 3:1. A essa mistura eram adicionados $50 \mathrm{~mL}$ de melaço de canade-açúcar para melhorar a palatabilidade. Além do volumoso, concentrado a base de milho e soja, era ofertado na proporção de $1 \%$ do peso corporal dos bovinos. Os Bovinos 1 a 4 receberam inicialmente $5 \mathrm{~g}$ de samambaia/kg de peso corporal; à medida que os bovinos se adaptavam a ingerir maior quantidades da planta, a dose era gradativamente aumentada até $15 \mathrm{~g} / \mathrm{kg}$. O Bovino 5 serviu de controle e recebia apenas feno à vontade e concentrado na mesma proporção dos demais bovinos. O pesos iniciais e finais dos bovinos, as quantidades de planta ingerida, a dose diária média e o tempo de administração encontram-se no Quadro 1.

Quadro 1. Peso inicial, quantidade de planta administrada, dose diária, tempo de administração e peso final dos bovinos na intoxicação experimental aguda por Pteridium aquilinum

\begin{tabular}{cccccc}
\hline Bovino & $\begin{array}{c}\text { Peso inicial } \\
(\mathrm{kg})\end{array}$ & $\begin{array}{c}\text { Total de } \\
\text { planta } \\
\text { ingerido } \\
(\mathrm{kg})\end{array}$ & $\begin{array}{c}\text { Tempo de } \\
\text { administração } \\
(\text { dias })\end{array}$ & $\begin{array}{c}\text { Dose } \\
\text { diária } \\
\text { média } \\
(\mathrm{g} / \mathrm{kg})^{\mathrm{a}}\end{array}$ & $\begin{array}{c}\text { Peso } \\
\text { final } \\
(\mathrm{kg})\end{array}$ \\
\hline 1 & 200 & 112,7 & 58 & 10,2 & 190 \\
2 & 190 & 107,6 & 58 & 10,5 & 170 \\
3 & 200 & 85,4 & 57 & 8,0 & 180 \\
4 & 215 & 90,2 & 53 & 8,6 & 190 \\
$5^{\mathrm{b}}$ & 225 & - & - & - & 300
\end{tabular}

a Foi considerada a média dos pesos inicial e final para obtenção dos valores das doses diárias médias; ${ }^{\mathrm{b}}$ Controle.

Hemograma, coagulograma, bioquímica sérica e hemocultura. Foram colhidos $15 \mathrm{~mL}$ de sangue da jugular de todos os bovinos antes da administração da planta (dia zero) e nos dias 30, 45, 53 após o início da ingestão da planta (AIP); coletas adicionais foram realizadas nos dias 56 (Bov.3) e 58 (Bov.2 e 5) AIP. Para realização do hemograma, que incluía eritrograma, leucograma e plaquetograma, foram utilizados $5 \mathrm{~mL}$ de sangue acondicionado em tubos com o anticoagulante ácido etilenodiaminotetracético (EDTA). Para realização de exames bioquímicos, que incluíam a determinação da atividade sérica das enzimas aspartato-aminotransferase (AST), gama-glutamiltransferase (GGT) e fosfatase alcalina (FA) e a mensuração da uréia e da creatinina, foram utilizados $5 \mathrm{ml}$ de sangue acondicionado em tubos sem anticoagulante. Para a realização do coagulograma, que incluía a determinação do tempo de protrombina (TP), do tempo de tromboplastina parcial ativada (TTPA) e dos produtos da degradação da fibrina (PDF), foram utilizados $4,5 \mathrm{ml}$ de sangue acondicionado em tubos contendo 0,5mL do anticoagulante citrato de sódio a 3,5\%.

As contagens sangüíneas foram realizadas em contadores celulares automatizados através do princípio da impedância elétrica; entretanto, o diferencial leucocitário foi realizado de forma manual. Os exames bioquímicos foram realizados sob automatização, por métodos enzimáticos (creatinina), cinéticos (AST e GGT) ou colorimétricos (FA e uréia), através de química seca. Os tempos de coagulação foram determinados através de técnicas convencionais, automatizadas (TTPA) ou manuais (TP). Os PDF foram determinados de forma semi-quantitativa, em que valores abaixo de $10 \mathrm{mg} / \mathrm{mL}$ são considerados negativos e valores acima de $10 \mathrm{mg} / \mathrm{mL}$ são considerados positivos.

Adicionalmente, pouco antes da morte dos Bovinos 1 a 4 , foram colhidos $10 \mathrm{~mL}$ de sangue da jugular. $\mathrm{O}$ mesmo procedimento foi realizado ao final do experimento com o Bovino 5. O sangue desses cinco bovinos foi acondicionado em meio nutritivo estéril para cultivo de bactérias aeróbicas e anaeróbicas. As amostras foram semeadas em ágar McConkey e ágar sangue e foram realizados testes bioquímicos para classificação dos isolados.

Biópsia aspirativa de medula óssea. Biópsia da medula óssea foi realizada através de punção aspirativa por agulha fina (PAAF) nos cinco terneiros do experimento. O local escolhido para todas as punções foi a superfície ventral do corpo do esterno, na altura da segunda ou terceira esternebra. A técnica para punção consistiu de: 1) tricotomia e anti-sepsia da região, anestesia local (pele ao periósteo) com $2 \mathrm{ml}$ de lidocaína a $2 \%$ sem vasoconstritor, perfuração da pele com agulha $40 \times 12 \mathrm{~mm}$ e punção do esterno. O conteúdo aspirado, cerca de $2 \mathrm{ml}$ de medula óssea, era imediatamente misturado ao EDTA presente no interior da seringa. Após homogeneização, os esfregaços eram pre-

Quadro 2. Intoxicação experimental aguda por Pteridium aquilinum em bovinos. Órgãos colhidos para histopatologia

\begin{tabular}{|c|c|c|c|c|c|}
\hline \multirow[t]{2}{*}{ Órgão } & \multicolumn{5}{|c|}{ Bovino } \\
\hline & 1 & 2 & 3 & 4 & 5 \\
\hline Abomaso & $\bullet$ & o & $\bullet$ & $\bullet$ & $\bullet$ \\
\hline Adrenal & $\bullet$ & $\bullet$ & $\bullet$ & $\bullet$ & o \\
\hline Baço & $\bullet$ & $\bullet$ & $\bullet$ & $\bullet$ & $\bullet$ \\
\hline Bexiga & $\bullet$ & $\bullet$ & $\bullet$ & $\bullet$ & ○ \\
\hline Coração & $\bullet$ & $\bullet$ & $\bullet$ & $\bullet$ & ○ \\
\hline Encéfalo & $\bullet$ & $\bullet$ & $\bullet$ & $\bullet$ & $\bullet$ \\
\hline Fígado & $\bullet$ & $\bullet$ & $\bullet$ & $\bullet$ & $\bullet$ \\
\hline Intestino delgado & $\bullet$ & $\bullet$ & $\bullet$ & $\bullet$ & $\bullet$ \\
\hline Intestino grosso & o & 0 & $\bullet$ & O & $\bullet$ \\
\hline Laringe & $\bullet$ & $\bullet$ & $\bullet$ & $\bullet$ & o \\
\hline Linfonodo pré-escapular & o & $\bullet$ & $\bullet$ & O & $\bullet$ \\
\hline Linfonodos hepáticos & o & ० & $\bullet$ & $\bullet$ & ○ \\
\hline Linfonodos mesentéricos & - & $\bullet$ & $\bullet$ & $\bullet$ & ○ \\
\hline Linfonodos poplíteos & o & o & $\bullet$ & ○ & ○ \\
\hline Linfonodos renais & o & o & $\bullet$ & $\bullet$ & ○ \\
\hline Linfonodos retrofaríngeos & $\bullet$ & $\bullet$ & $\bullet$ & $\bullet$ & $\bullet$ \\
\hline Músculo esquelético & o & o & $\bullet$ & o & o \\
\hline Medula óssea (esternebra) & & & & & $\bullet$ \\
\hline Omaso & $\bullet$ & ० & o & o & $\bullet$ \\
\hline Pulmão & $\bullet$ & $\bullet$ & $\bullet$ & $\bullet$ & $\bullet$ \\
\hline Retículo & ० & $\circ$ & $\bullet$ & $\bullet$ & ० \\
\hline Reto & $\bullet$ & ○ & $\bullet$ & $\bullet$ & ○ \\
\hline Rim & $\bullet$ & $\bullet$ & $\bullet$ & $\bullet$ & $\bullet$ \\
\hline Rúmen & $\bullet$ & 0 & $\bullet$ & o & $\bullet$ \\
\hline Testículos & $\bullet$ & ० & o & $\bullet$ & ○ \\
\hline Timo & o & $\bullet$ & $\bullet$ & $\bullet$ & ○ \\
\hline Tonsilas & $\bullet$ & $\bullet$ & $\bullet$ & $\bullet$ & ○ \\
\hline Traquéia & o & $\bullet$ & o & 0 & ○ \\
\hline Ureteres & ० & ० & o & $\bullet$ & ○ \\
\hline Vesícula biliar & O & $\bullet$ & o & o & ○ \\
\hline
\end{tabular}

(\%) colhido e examinado histologicamente; (\%) não colhido. 
parados e, em seguida, corados com panótico rápido. A PAAF da medula óssea dos Bovinos 2 a 4 foi realizada pouco antes da morte, já a PAAF dos Bovinos 1 e 5 foi realizada logo após a morte e ao final do experimento, respectivamente.

Necropsia e histopatologia. A necropsia dos cinco bovinos foi realizada até duas horas após a morte. Foram colhidos fragmentos de diversos órgãos (Quadro 2). Esses fragmentos eram fixados em formol a $10 \%$, processados rotineiramente para histopatologia e corados pela hematoxilina e eosina. Fragmentos de intestino do Bovino 4 foram adicionalmente corados pelo método do ácido periódico de Schiff (PAS). O encéfalo foi fixado inteiro; após a fixação foi realizado o exame macroscópico
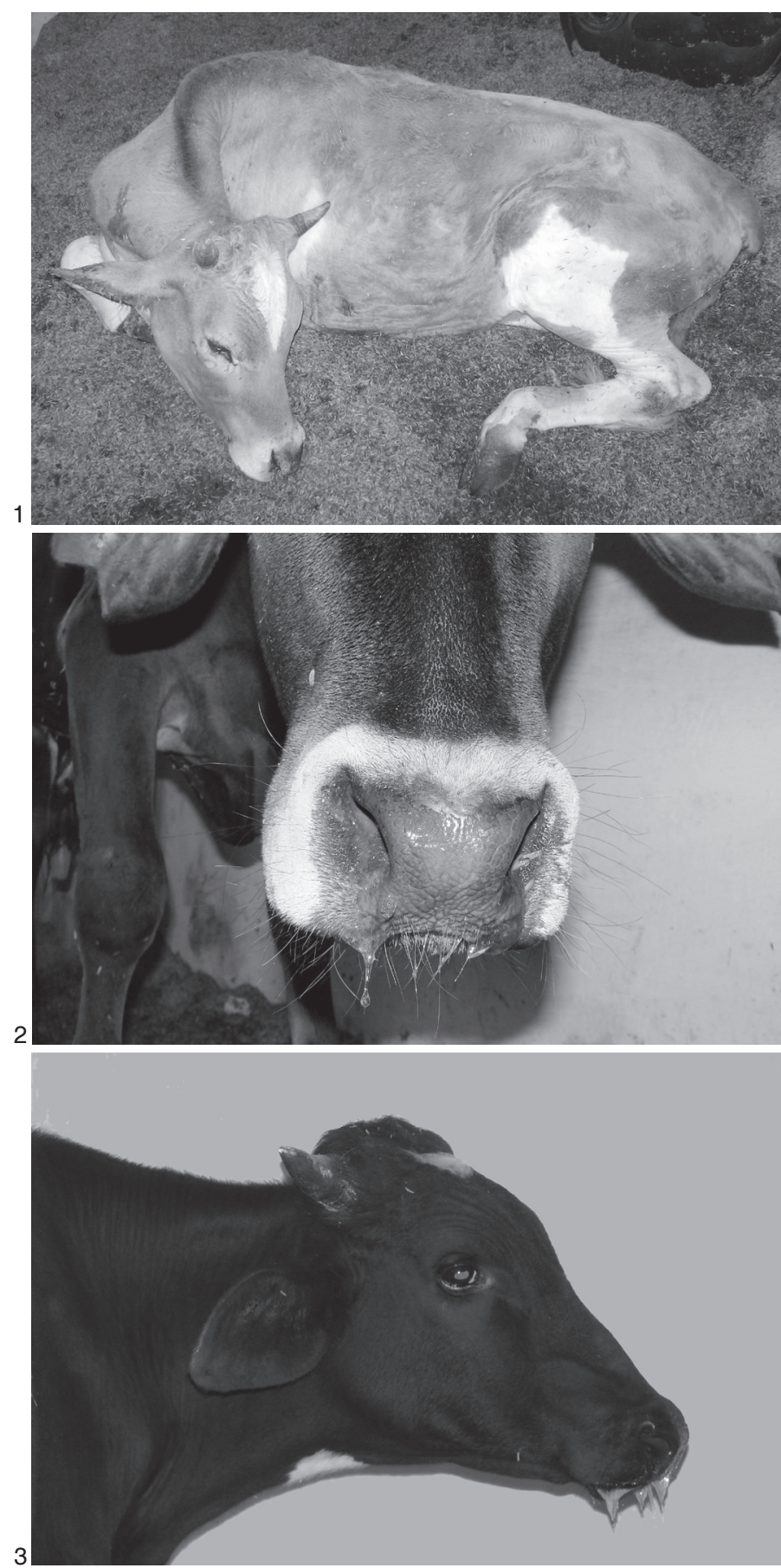

através de cortes transversais feitos com intervalos de $1 \mathrm{~cm}$ e fragmentos das seguintes regiões foram selecionados para exame histológico: 1) lobo frontal (na altura do joelho do corpo caloso e dos núcleos da base), 2) lobo parietal, 3) hipocampo, 4) tálamo, 5) mesencéfalo (na altura dos colículos rostrais), 6) cerebelo, 7) ponte com pedúnculos cerebelares e 8) bulbo (na altura do óbex).

\section{RESULTADOS}

\section{Achados clínicos}

Todos os bovinos do experimento, que receberam a planta, morreram espontaneamente (Bov.1-3) ou foram sacrificados quando moribundos (Bov.4), após apresentarem um quadro clínico com evolução de 5-6 dias. A quantidade de planta ingerida correspondeu, respectivamente, a $59,3 \%, 63,3 \%, 47,4 \%$ e $47,5 \%$ do peso dos Bovinos 1-4. O tempo decorrido desde o início da ingestão da planta até os primeiros sinais clínicos foi de 47-53 dias.

Os sinais clínicos iniciavam por moderada elevação da temperatura que progredia para picos febris de $41,8-42,5^{\circ} \mathrm{C}$; discreta apatia que se tornava pronunciada (Fig.1), à medida que progredia o curso clínico, ulcerações com sangramento na mucosa das narinas (Fig.2), salivação exces-

Fig.1. Bovino 2 demonstrando acentuada apatia na intoxicação experimental aguda por samambaia (Pteridium aquilinum).

Fig.2. Bovino 3 com sangramento pelas narinas na intoxicação experimental aguda por samambaia (Pteridium aquilinum).

Fig.3. Bovino 4 com salivação excessiva na intoxicação experimental aguda por samambaia (Pteridium aquilinum).

Fig.4. Bovino 3 com diarréia sanguinolenta na intoxicação experimental aguda por samambaia (Pteridium aquilinum).

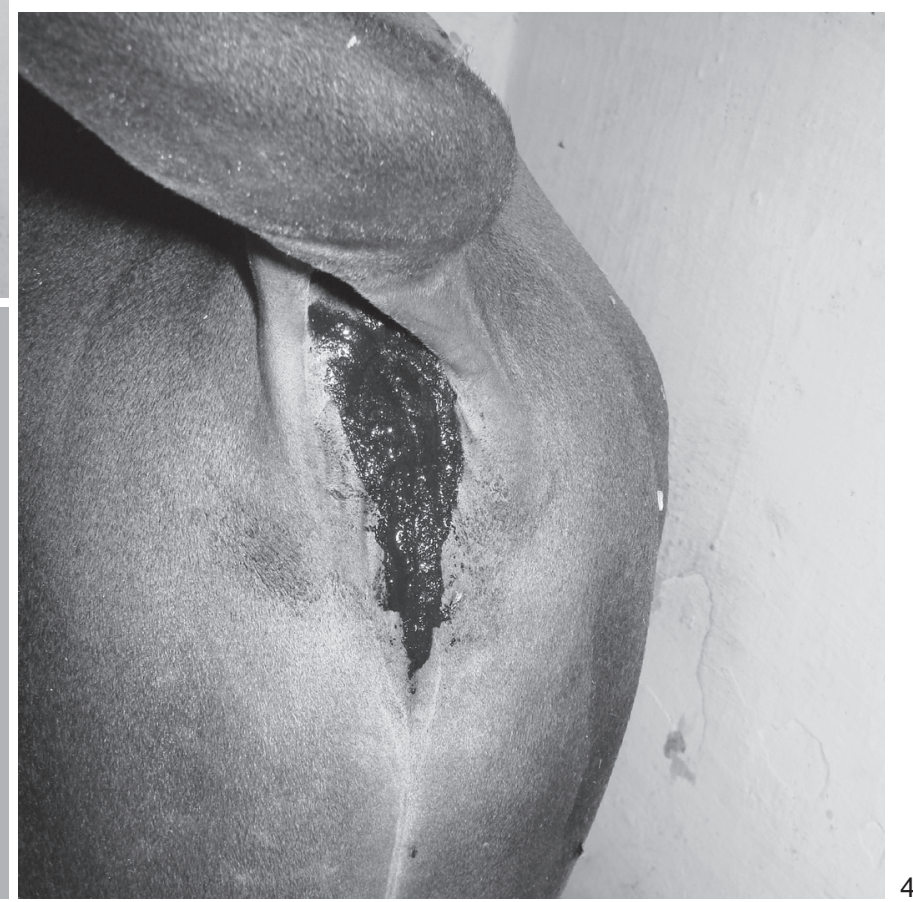




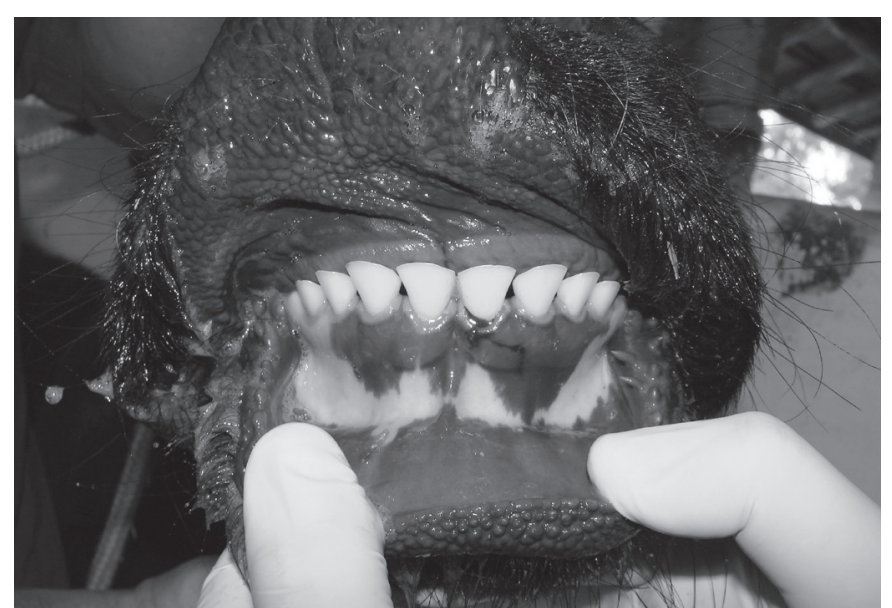

Fig.5. Bovino 4 com gengivorragia na intoxicação experimental aguda por samambaia (Pteridium aquilinum).

siva (Fig.3) e debilidade caracterizada por andar cambaleante e arrastar das pinças. Os bovinos apresentaram ainda fezes fétidas, enegrecidas ou misturadas com sangue (Fig.4), taquicardia, taquipnéia, anorexia, gengivorragia (Fig.5), leve palidez das mucosas oculares, petéquias nas mucosas ocular, oral e prepucial. Ao serem submetidos a coletas sanguíneas apresentaram sangramento por mais

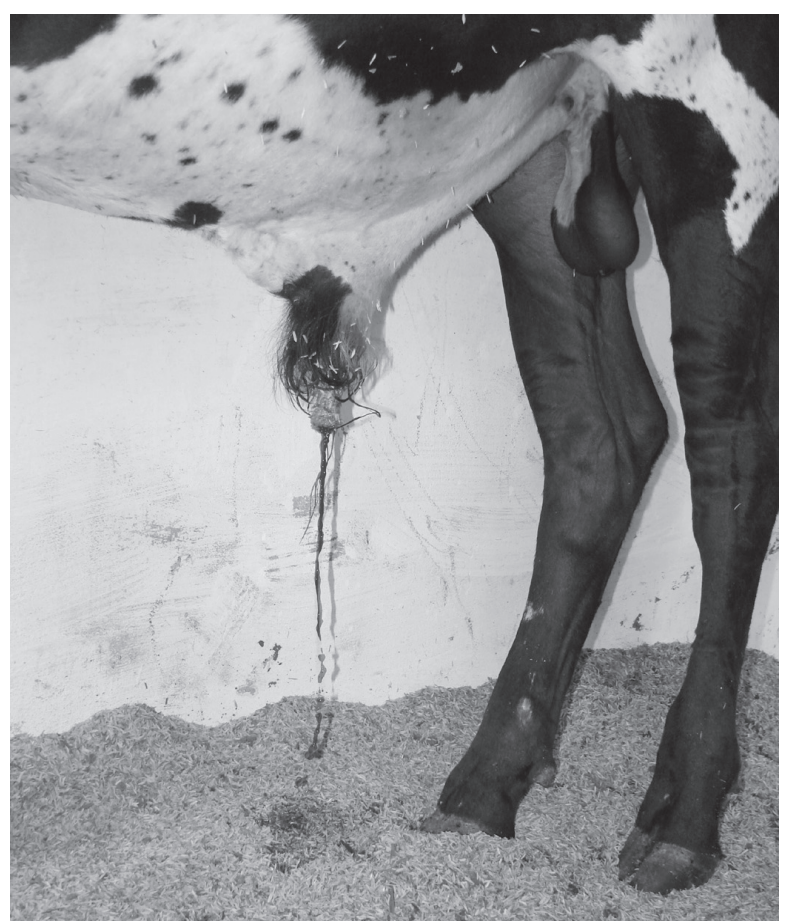

Fig.6. Bovino 4 com hematúria na intoxicação experimental aguda por samambaia (Pteridium aquilinum).

\section{Quadro 3. Evolução da doença e sinais clínicos na intoxicação experimental aguda por Pteridium aquilinum em bovinos}

\begin{tabular}{cc}
\hline Bovino & Evolução clínica \\
\hline 1 & 6 dias \\
& $(53-58$ dias AIPa $)$
\end{tabular}

53ํ dia AIP: hematúria leve. Petéquias na mucosa oral e ocular $\mathrm{TR}^{\mathrm{b}}$ de $38,9^{\circ} \mathrm{C}$. $\mathbf{5 4}^{\circ}$ dia AIP: apatia e inapetência leves, discretos coágulos de sangue nas fezes e leve sialorréia. 55으 dia AIP: dificuldade respiratória com discretos estertores (ronco) permanecendo assim até o dia 58 AIP. 57 dia AIP: hematúria acentuada e polaquiúria. Petéquias e equimoses na mucosa oral e ocular TR de $41,9^{\circ} \mathrm{C}$. Sialorréia acentuada, diarréia sanguinolenta fétida e enegre cida, bruxismo, desequilíbrio, mioclonias, pêlos arrepiados e mucosas oculares, oral e do prepúcio pálidas. $\mathbf{5 8}$ dia AIP: hematúria acentuada, atonia ruminal, aumento da $\mathrm{FC}^{\mathrm{C}}$ e $\mathrm{FR}^{\mathrm{d}}$ e respiração diafragmática pouco antes da morte. Baixa da TR para $38,5^{\circ} \mathrm{C}$; morte.

26 dias (53-58 dias AIP)

53 dia AIP: apresentou apenas hematúria leve. descarga nasal mucossanguinolenta leve. 54 dia AIP: petéquias na mucosa oral e ocular, TR de $39,7^{\circ} \mathrm{C}$. 55 dia AIP: TR de $41,8^{\circ} \mathrm{C}$. Apatia e inapetência leves. Descarga nasal mucossanguinolenta leve. 56 dia AIP: discretos coágulos de sangue nas fezes que evoluíram para acentuados nos dias seguintes. 57을 $^{-}$dia AIP: hematúria acentuada com polaquiúria; equimoses na mucosa oral e ocular; apatia e inapetência; TR de $41,5^{\circ} \mathrm{C}$. Diarréia sanguinolenta fétida e enegrecida, leve sialorréia, dificuldade respiratória com discretos estertores (ronco) que permaneceram até o dia 58 AIP e mucosas oral, ocular e do prepúcio pálidas. 58을 Aia Al descarga nasal mucossanguinolenta leve. Bruxismo, gengivorragia, desequilíbrio, mioclonias e pêlos arrepiados e atonia ruminal, além do aumento da FC e FR e respiração diafragmática pouco antes da morte. 52을 dia AIP: TR de $39^{\circ} \mathrm{C}$. $\mathbf{5 3}^{\circ}$ dia AIP: TR de $42,2^{\circ} \mathrm{C}$; hematúria leve. $\mathbf{5 4}^{\circ}$ dia AIP: apatia e inapetência leves. $5^{\circ}$ (52-57 dias AIP) dia AIP: Hematúria acentuada com polaquiúria. Petéquias na mucosa oral e ocular. Leve dificuldade respiratória com discretos estertores (ronco). Úlceras leves na mucosa nasal. Acentuada diarréia sanguinolenta fétida e ene grecida e mucosas oculares, oral e do prepúcio pálidas. 56 dia AIP: Hematúria acentuada com polaquiúria. Petéquias e equimoses na mucosa oral e ocular, apatia e inapetência acentuadas. Moderados coágulos de sangue nas fezes (consistência normal); leve sialorréia e descarga nasal mucossanguinolenta. Moderada dificuldade respiratória com discretos estertores (ronco); úlceras leves com sangramento na mucosa nasal. 570 dia AIP: TR de $39,0^{\circ} \mathrm{C}$; sialorréia e descarga nasal mucossanguinolenta acentuadas. Apresentou bruxismo, gengivorragia, desequilíbrio, mioclonias, pêlos arrepiados e atonia ruminal, além de aumento da FC e FR e respiração diafragmática. Acentuada dificuldade respiratória com discretos estertores (ronco); morte.

7 dias (47-53 dias AIP)

47 dias AIP: TR de $39,1^{\circ} \mathrm{C} . \mathbf{5 1}$ dias AIP: apatia e inapetência leves. 52 dias AIP: TR de $42,5^{\circ} \mathrm{C}$; apatia e inapetência acentuadas. Hematúria com polaquiúria, equimoses, dificuldade respiratória com estertores (ronco) moderados. 53 dias AIP: TR de $42,2^{\circ} \mathrm{C}$ Hematúria com polaquiúria, equimoses, dificuldade respiratória com estertores (ronco) acentuados. Mucosas oculares, oral e do prepúcio pálidas; descarga nasal mucossanguinolenta moderada; bruxismo, gengivorragia, desequilíbrio, mioclonias e pêlos arrepiados, atonia ruminal, aumento da FC e FR e respiração diafragmática pouco antes da morte.

5 Não adoeceu Sem alterações

\footnotetext{
${ }^{\mathrm{a} A I P}=$ Após o início do experimento; ${ }^{\mathrm{b}}$ Temperatura retal; ${ }^{\mathrm{c}}$ Freqüência cardíaca, ${ }^{\mathrm{c}}$ Freqüência respiratória.
} 


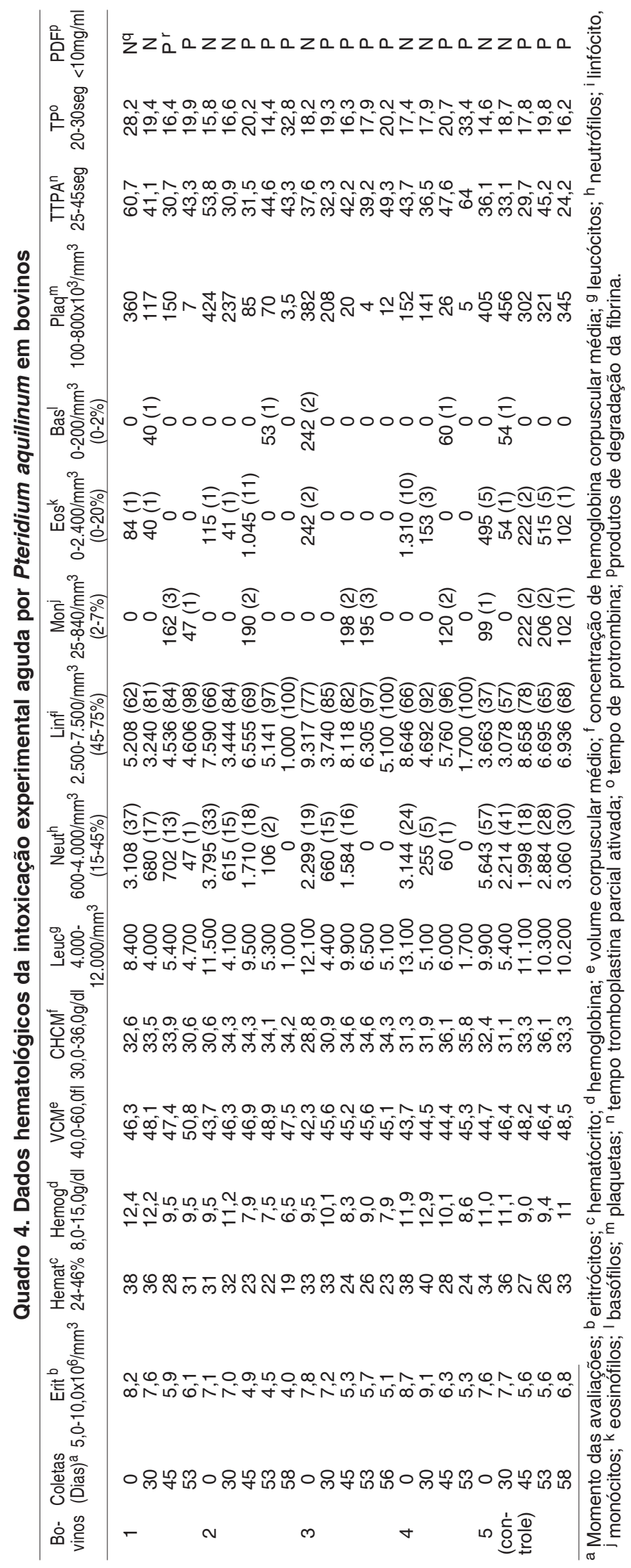

de 12 horas no local da venopunção, indicando tempo de sangramento acentuadamente prolongado. Todos os bovinos apresentaram hematúria acentuada (Fig.6) com polaquiúria. Foi observada perda de peso em todos os bovinos do experimento quando comparados com o bovino controle (Quadro 1). Os sinais clínicos de cada bovino estão apresentados em ordem cronológica no Quadro 3.

\section{Hemograma, coagulograma, bioquímica séricae hemocultura}

As alterações hematológicas observadas ao longo do experimento em cada bovino estão detalhadas no Quadro 4. Os hemogramas dos quatro bovinos intoxicados revelaram marcada diminuição na quantidade de neutrófilos, 30 dias AIP. Nesse mesmo período, o bovino controle (Bov.5) demonstrou leve diminuição no número de neutrófilos circulantes. Entretanto, embora todos os quatro bovinos intoxicados tenham diminuído muito o número de neutrófilos na circulação, apenas um (Bov.4) pôde ser considerado neutropênico nesse momento do experimento. Aos 45 dias, três dos quatro bovinos intoxicados (Bov.1-3) tiveram variável aumento na contagem absoluta de neutrófilos. Diferentemente desses, o Bovino 4 tornou-se mais gravemente neutropênico. Aos 53 dias, todos os quatro bovinos intoxicados demonstravam acentuada diminuição na quantidade de neutrófilos e estavam marcadamente neutropênicos. Dois desses quatro bovinos não apresentavam neutrófilos circulantes e dois apresentavam apenas 1\%-2\% de neutrófilos no diferencial de leucócitos. Nesse mesmo período, embora os leucócitos totais tenham acompanhado proporcionalmente as oscilações do número de neutrófilos, só ocorreu diminuição abaixo dos valores de referência, ou seja, leucopenia, no Bovino 4. Outro bovino (Bov.2) demonstrou leucopenia aos 58 dias. Assim, do total de quatro bovinos intoxicados, quatro tornaram-se neutropênicos e apenas dois tornaram-se leucopênicos. Embora dois dos quatro bovinos (Bov.2 e 4) tenham tido marcada diminuição nas contagens absolutas de linfócitos, os valores relativos de todos os quatro bovinos sempre estiveram ao redor de $100 \%$ no período ante-morte.

Todos os quatro bovinos intoxicados demonstraram diminuição do éritron, caracterizada por decréscimo da contagem de eritrócitos, da concentração de hemoglobina e do hematócrito. Essa diminuição já podia ser vista a partir da segunda coleta de sangue, aos 45 dias AIP. Entretanto, o bovino controle também demonstrou diminuição do éritron no mesmo período e na mesma proporção. Dois dos quatro bovinos (Bov.2 e 4) demonstraram uma pequena diminuição dos valores eritrocitários entre os dias 45 e 53 , enquanto outros dois bovinos (Bov.1 e 3 ) demonstraram leve aumento nesses valores no mesmo período. O bovino controle comportou-se quanto aos parâmetros eritróides de forma semelhante aos Bovinos 2 e 4 . Assim, dos quatro bovinos intoxicados, apenas dois (Bov.2 e 3) ficaram anêmicos durante o experimento e todos, inclusive o bovino controle, demonstraram diminuição dos parâmetros eritróides. Esses dois bovinos tinham anemia leve, não 


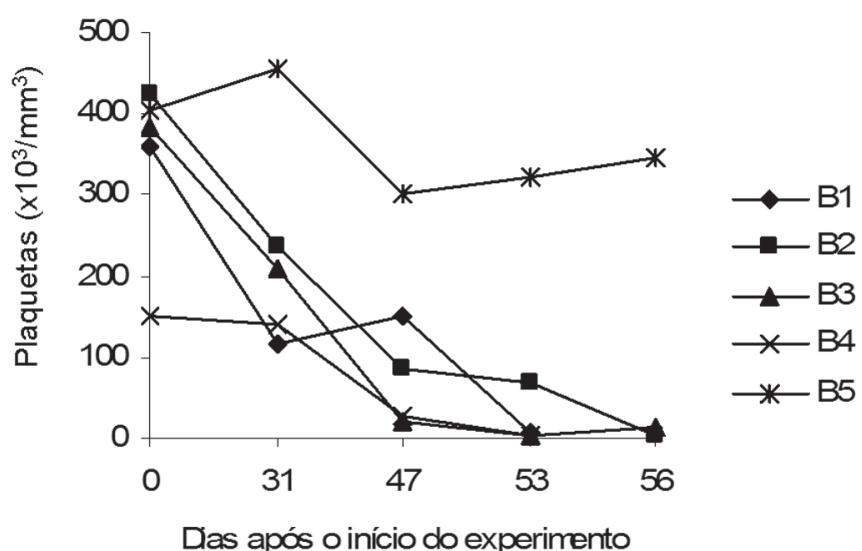

Fig.7. Representação gráfica do plaquetograma dos cinco bovinos usados no experimento de intoxicação experimental aguda por Pteridium aquilinum em bovinos. B1-B4 são os bovinos que receberam a planta. B5 é o bovino controle.

demonstraram na circulação indícios de regeneração medular (anemia arregenerativa) e apresentavam o volume corpuscular médio (VCM) e a concentração de hemoglobina corpuscular média ( $\mathrm{CHCM}$ ) dentro dos parâmetros de referência (anemia normocítica normocrômica).

Os plaquetogramas dos quatro bovinos intoxicados revelaram variável diminuição na quantidade de plaquetas 30 dias AIP. Entretanto, embora todos os quatro bovinos intoxicados tenham diminuído o número de plaque-

\section{Quadro 5. Achados da bioquímica sérica observados nos quatro bovinos intoxicados experimentalmente por Pteridium aquilinum e num bovino controle}

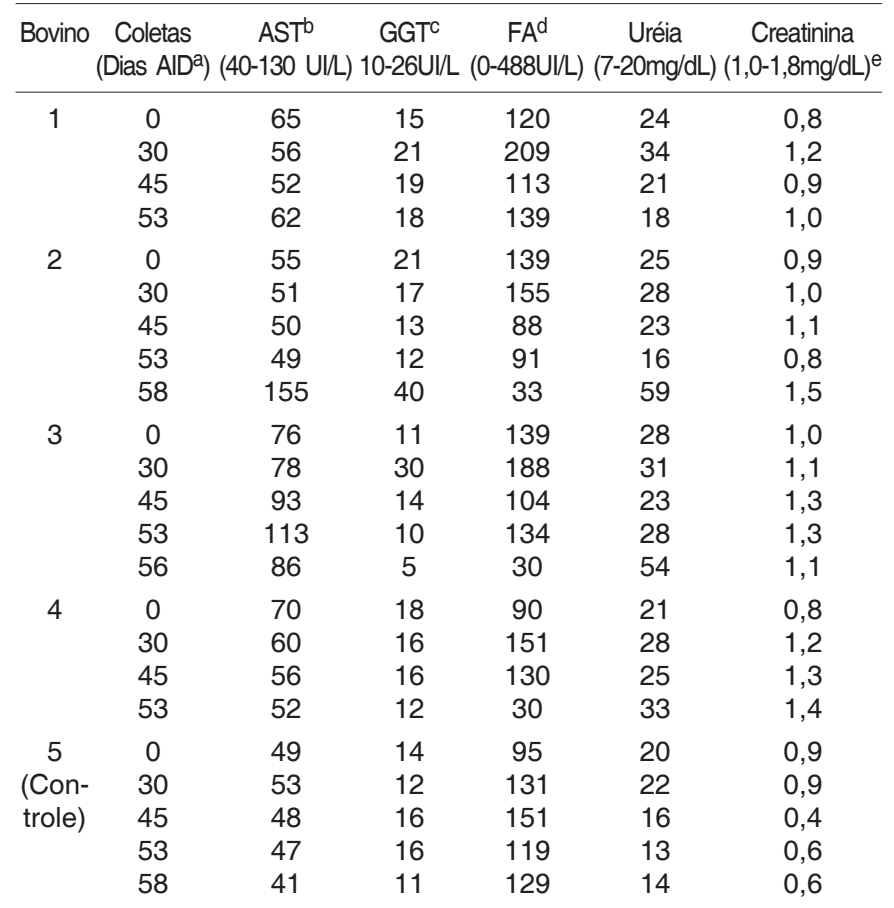

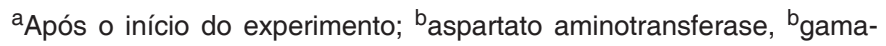
glutamiltransferase, " ${ }^{C}$ osfatase alcalina; ${ }^{e}$ os números entre parênteses após o nome do parâmetro são os valores de referência. tas na circulação, nenhum pôde ser considerado trombocitopênico nesse momento do experimento. Aos 45 dias, três dos quatro bovinos intoxicados (Bov.2-4) diminuíram ainda mais o número de plaquetas e tornaramse trombocitopênicos. A gravidade da trombocitopenia nesses três bovinos variava de leve (Bov.2) a moderada (Bov.3 e 4). Aos 53 dias, todos os quatro bovinos intoxicados estavam trombocitopênicos. A gravidade da trombocitopenia nesses quatro bovinos variava de leve (Bov.2) a acentuada (Bov.1-4). O Bovino 2 só se tornou marcadamente trombocitopênico aos 58 dias AIP. Nesse mesmo período, o bovino controle (Bov.5) demonstrou leve oscilação na quantidade de plaquetas, mas sempre com parâmetros dentro da faixa de normalidade para a espécie. As variações no plaquetograma dos cinco bovinos do experimento podem ser observadas na Figura 7.

Os coagulogramas demonstraram marcada variação nos diferentes momentos do experimento. Tais variações observadas ao longo do experimento em cada bovino estão detalhadas no Quadro 4.

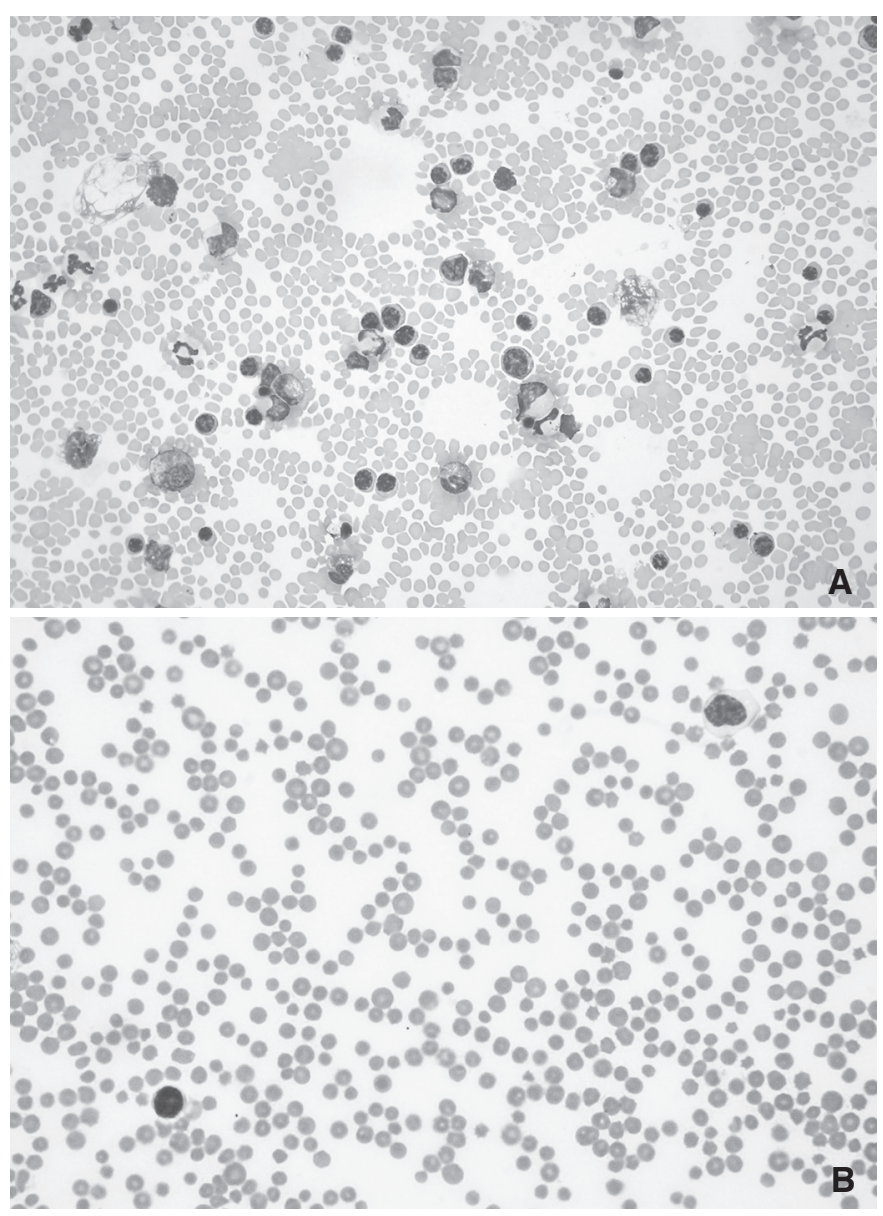

Fig.8. Esfregaços realizados a partir dos aspirados por agulha fina realizada em bovinos utilizados no experimento de intoxicação experimental aguda por Pteridium aquilinum. (A) Bovino 5 (controle) mostrando medula óssea normal. (B) Bovino 3, mostrando ausência de células das três linhagens medulares, indicando aplasia de medula óssea. Panótico, obj.40x. 
Quadro 6. Intensidade das lesões de acordo com a localização anatômica na intoxicação experimental aguda por Pteridium aquilinum em bovinos

\begin{tabular}{|c|c|c|c|c|c|}
\hline \multirow[t]{2}{*}{ Lesão } & \multirow[t]{2}{*}{ Órgão afetado } & \multicolumn{4}{|c|}{ Bovino } \\
\hline & & 1 & 2 & 3 & 4 \\
\hline \multirow{42}{*}{ Hemorragia } & Abomaso & $++^{\mathrm{a}}$ & $++^{\mathrm{b}}$ & $+++\mathrm{C}$ & + \\
\hline & Adrenais & $-d$ & - & + & +++ \\
\hline & Articulações & +++ & +++ & +++ & +++ \\
\hline & Baço & + & +++ & +++ & +++ \\
\hline & Bexiga & +++ & +++ & +++ & +++ \\
\hline & Ceco & +++ & +++ & +++ & - \\
\hline & Conjuntiva & ++ & ++ & ++ & ++ \\
\hline & Coração & ++ & - & +++ & +++ \\
\hline & Diafragma & +++ & - & + & + \\
\hline & Esôfago & + & - & - & - \\
\hline & Fígado & + & + & +++ & - \\
\hline & Intestino delgado & +++ & + & +++ & ++ \\
\hline & Cólon & +++ & ++ & +++ & ++ \\
\hline & Laringe/faringe & ++ & - & +++ & +++ \\
\hline & Linfonodos pré-escapulares & - & + & + & - \\
\hline & Linfonodos hepáticos & - & - & + & + \\
\hline & Linfonodos jejunais & - & - & +++ & - \\
\hline & Linfonodos poplíteos & - & - & + & - \\
\hline & Linfonodos renais & - & - & + & + \\
\hline & Linfonodos retrofaríngeos & +++ & - & +++ & +++ \\
\hline & Língua & + & - & + & ++ \\
\hline & Medula espinhal & + & ++ & - & - \\
\hline & Mesentério & ++ & - & +++ & ++ \\
\hline & Músculos esqueléticos & - & + & +++ & - \\
\hline & Omaso & + & +++ & ++ & + \\
\hline & Omento & ++ & ++ & ++ & - \\
\hline & Pelve renal & ++ & ++ & +++ & +++ \\
\hline & Peritônio & - & ++ & - & - \\
\hline & Pulmão & - & ++ & - & - \\
\hline & Retículo & + & - & ++ & + \\
\hline & Reto & ++ & - & - & +++ \\
\hline & Rim (cálices) & +++ & ++ & +++ & +++ \\
\hline & Rúmen & + & - & - & + \\
\hline & Seios frontais & - & - & +++ & - \\
\hline & Subcutâneo & ++ & ++ & ++ & +++ \\
\hline & Testículos & +++ & $-e$ & +++ & +++ \\
\hline & Timo & ++ & - & +++ & +++ \\
\hline & Tonsila & + & - & ++ & +++ \\
\hline & Traquéia & ++ & ++ & - & - \\
\hline & Ureteres & +++ & - & +++ & +++ \\
\hline & Uretra (porção peniana) & + & - & ++ & - \\
\hline & Vesícula biliar & + & +++ & + & +++ \\
\hline \multirow[t]{2}{*}{ Edema } & Laringe & ++ & - & ++ & +++ \\
\hline & Pulmão & +++ & +++ & - & - \\
\hline Infarto & Fígado & +++ & +++ & - & - \\
\hline Úlcera & Abomaso & - & - & ++ & - \\
\hline
\end{tabular}

$\bar{a}(++)$ moderada; ${ }^{b}(+)$ leve $; ~{ }^{c}(+++)$ acentuada; ${ }^{d}(-)$ ausente; ${ }^{e}$ macho castrado.

As alterações da bioquímica sérica observadas ao longo do experimento em cada bovino estão detalhadas no Quadro 5. Dos quatro bovinos intoxicados, todos demonstraram leve aumento nos níveis séricos de uréia em algum momento do experimento. Desses quatro bovinos, três (Bov.2-4) demonstraram aumento mais acentuado na última coleta, ou seja, no período ante-morte. Houve leve aumento da GGT em dois (Bov.2 e 3) dos quatro bovinos intoxicados. Um desses bovinos (Bov.2) também demonstrou aumento da AST. Não foram observadas alterações nos níveis séricos da creatinina e na atividade sérica da fosfatase alcalina dos bovinos que ingeriram a planta. $\mathrm{Na}$ cultura, as amostras de sangue provenientes dos Bovinos 1-3 foram positivas para Klebsiella oxytoca, Staphylococcus hyicus e Staphylococcus aureus, respectivamente.

\section{Biópsia aspirativa da medula óssea}

Os esfregaços de medula óssea dos quatro bovinos intoxicados apresentaram acentuada diminuição na quantidade de células hematopoéticas das três linhagens medulares (megacariocítica, mielóide e eritróide), o que caracteriza insuficiência medular decorrente de aplasia (Fig.8A). Os compartimentos megacariocítico e mielóide foram os mais afetados. Em todos os bovinos havia ausência de megacariócitos e diminuição da relação mielóide:eritróide. As únicas células presentes nos esfregaços de medula óssea eram precursores eritróides, principalmente

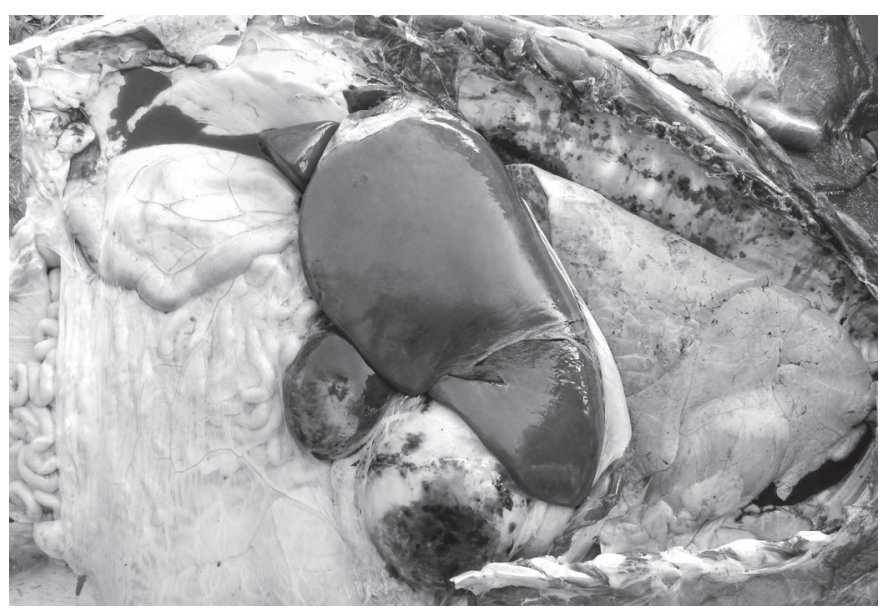

Fig.9. Hemorragias em várias serosas das cavidades abdominal e torácica do Bovino 2 na intoxicação experimental aguda por Pteridium aquilinum. Observam-se principalmente hemorragias na serosa do omaso, na parede da vesícula biliar, no lobo diafragmático do pulmão e na pleura parietal ao longo das vértebras.

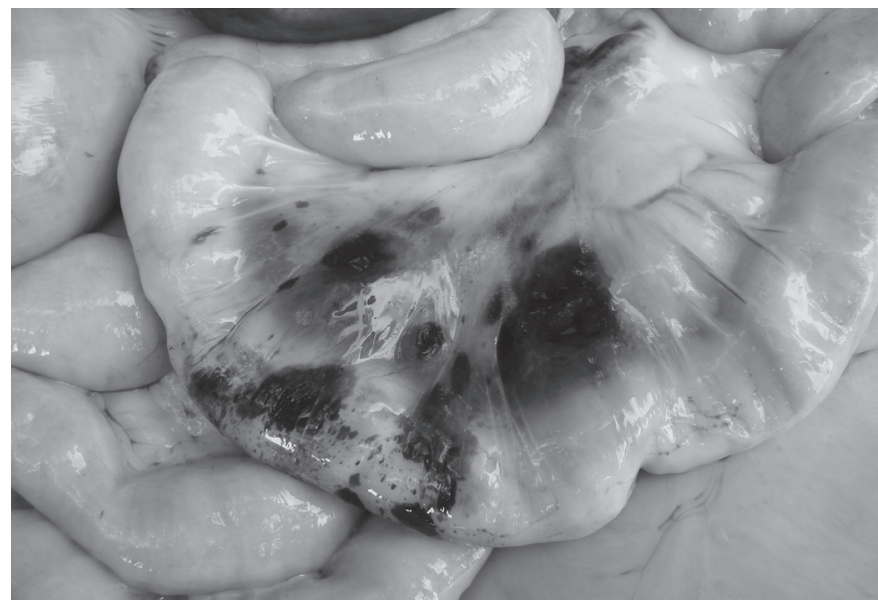

Fig.10. Hemorragias na parede do intestino e no mesentério do Bovino 4 na intoxicação experimental aguda por Pteridium aquilinum. 

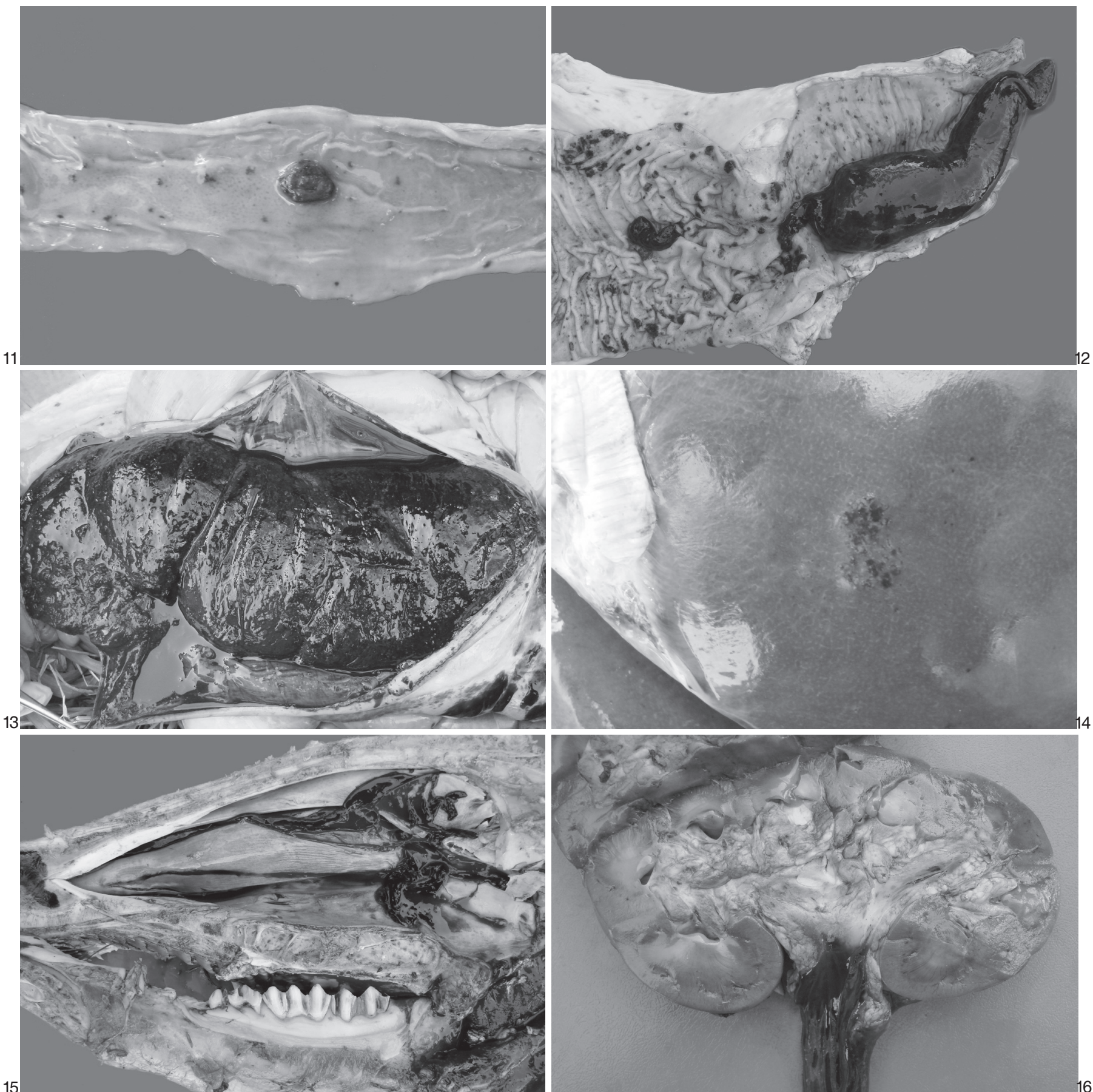

Fig.11. Hemorragia na mucosa intestinal sobre uma placa de Peyer do Bovino 4 na intoxicação experimental aguda por Pteridium aquilinum. Essas hemorragias eram, na maioria das vezes, transmurais correspondiam a hemorragias de mesma localização na parede e serosa do órgão (ver Fig.10)

Fig.13. Grande coágulo de sangue no ceco Bovino 1 na intoxicação experimental aguda por Pteridium aquilinum.

Fig.15. Coágulos de sangue nos seios nasais do e nos cornetos do Bovino 3, na intoxicação experimental aguda por Pteridium aquilinum.

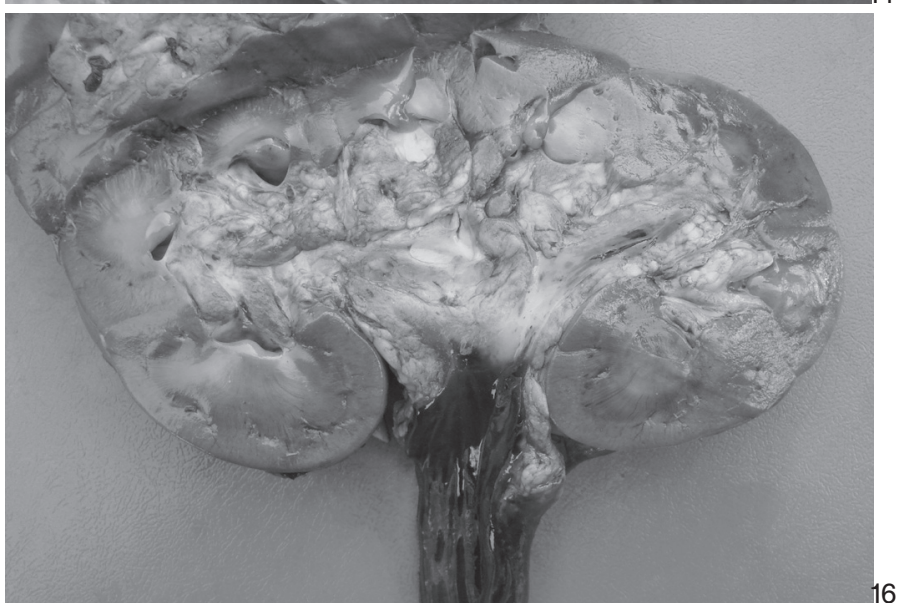

Fig.12. Grande coágulo de sangue na porção pilórica do abomaso do Bovino 3 na intoxicação experimental aguda por Pteridium aquilinum.

Fig.14. Infarto firme, com áreas brancacentas e entremeado por hemorragia no fígado do Bovino 2, na intoxicação na intoxicação experimental aguda por Pteridium aquilinum.

Fig.16. Hemorragia nos cálices renais que se estende até os ureteres do Bovino 1, na intoxicação experimental aguda por Pteridium aquilinum. 
metarrubrícitos e rubrícitos. Precursores mielóides eram apenas ocasionalmente observados nos esfregaços. 0 Bovino 5 apresentou uma medula óssea normal com grande quantidade de células das linhagens mielóide, eritróide e megacariocítica (Fig.8B).

\section{Achados de necropsia}

Hemorragias leves a acentuadas foram observadas em vários órgãos nos Bovinos 1-4 e sua distribuição e intensidades estão no Quadro 6. Grande número de petéquias e sufusões era observado no tecido subcutâneo, nas áreas de atrito ou trauma, principalmente nas faces laterais da cavidade abdominal, na altura das últimas costelas e sobre o esterno (área de punção da medula óssea). Na

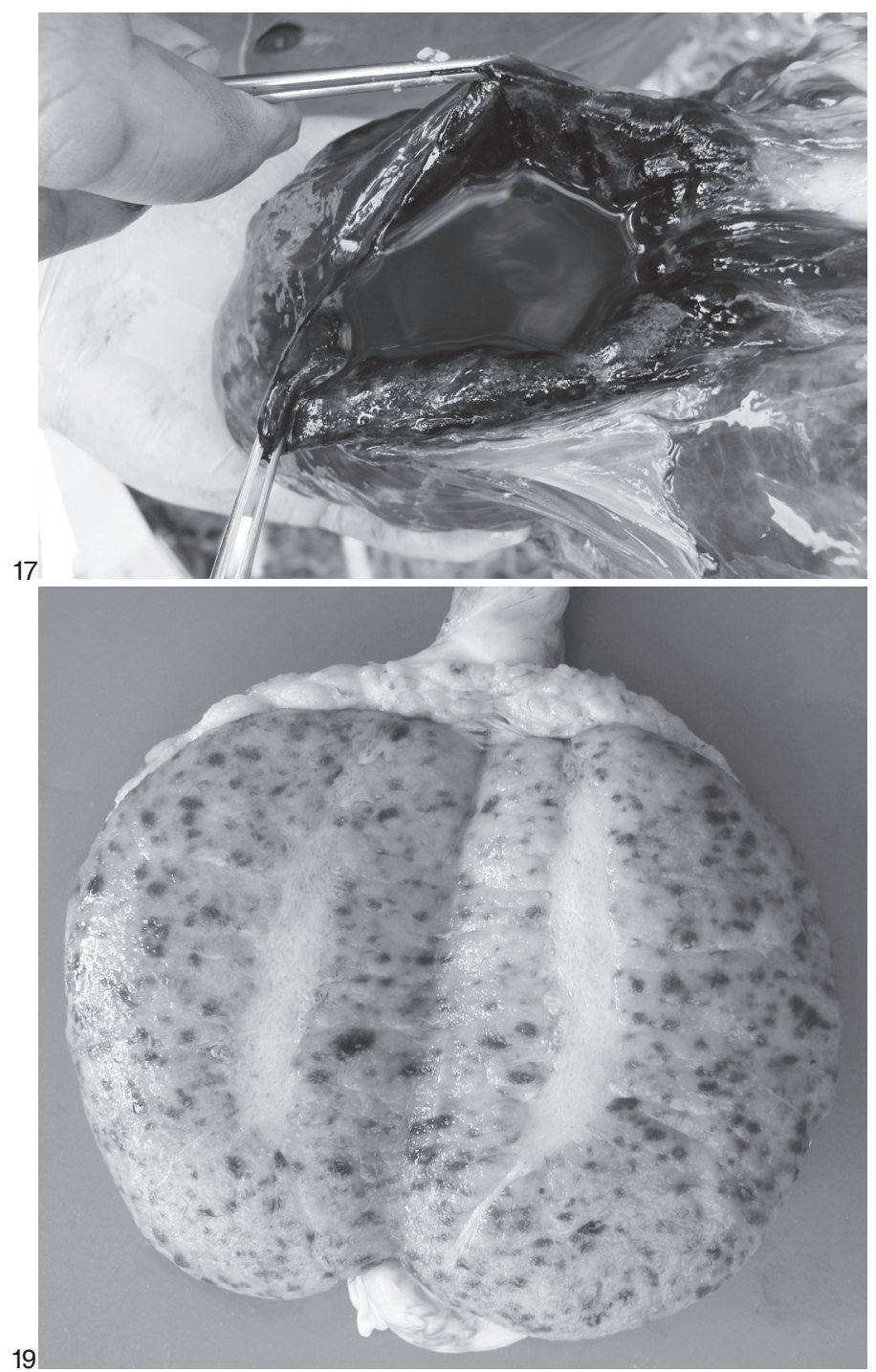

Fig.17. Urina com sangue na bexiga do Bovino 4 na intoxicação experimental aguda por Pteridium aquilinum.

Fig.19. Testículo do Bovino 4 na intoxicação experimental aguda por Pteridium aquilinum. Observam-se hemorragias multifocais distribuídas por todo o parênquima testicular. laringe e faringe de três bovinos havia edema acentuado com oclusão parcial da rima da glote; os tecidos adjacentes a essa região eram acentuadamente hemorrágicos e edematosos. Numerosas petéquias e sufusões ocorriam em praticamente todas as serosas dos órgãos da cavidade abdominal. Áreas de hemorragia arredondadas, com bordos irregulares com $2-3 \mathrm{~cm}$ de diâmetro eram observadas na serosa do rúmen, retículo, omaso (Fig.9), abomaso e intestinos (Fig.10); áreas de hemorragia semeIhantes eram observadas na mucosa desses órgãos, nos locais correspondentes às hemorragias das serosas. No caso do intestino delgado, essas áreas correspondiam às placas de Peyer (Fig.11). Na porção pilórica do abomaso do Bovino 3 havia um coágulo de sangue cilíndrico de
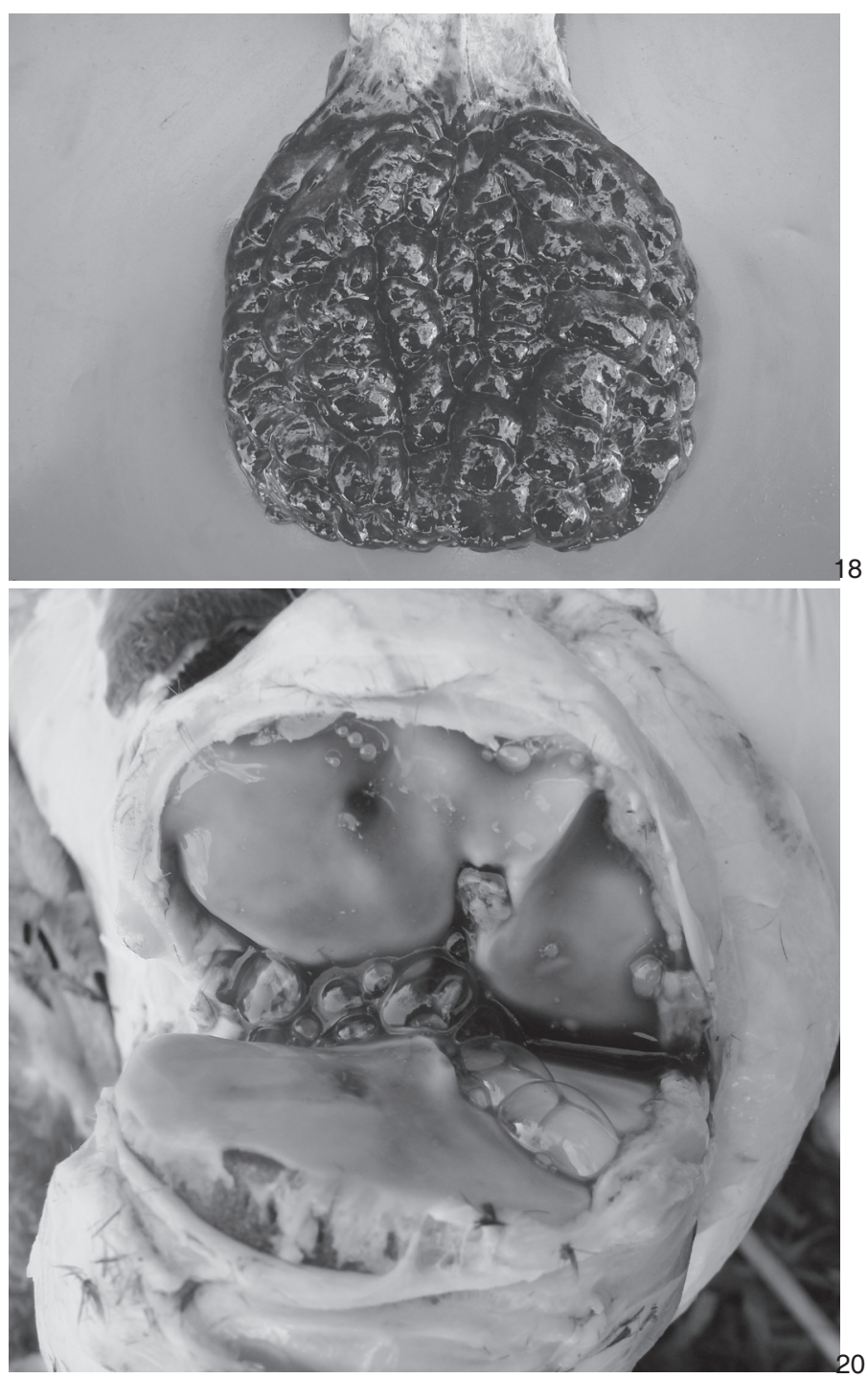

Fig.18. Bexiga do Bovino 3 na intoxicação experimental aguda por Pteridium aquilinum. A mucosa vesical e os tecidos subjacentes estão acentuadamente edemaciados e hemorrágicos.

Fig.20. Hemartrose na articulação carpometacárpica direita do Bovino 3 na intoxicação experimental aguda por Pteridium aquilinum. 
$6 \mathrm{~cm}$ de diâmetro e $15 \mathrm{~cm}$ de comprimento (Fig.12). Coágulos de sangue semelhantes eram observados no ceco (Fig.13) e cólon em dois outros bovinos. Múltiplas petéquias eram também vistas no mesentério, principalmente junto a inserção deste ao intestino. Múltiplas hemorragias subcapsulares no fígado e múltiplos pequenos focos $(0,1-0,2 \mathrm{~cm})$ brancos de necrose apareciam de distribuídos por todo o parênquima hepático. Dois infartos de contornos geométricos e $2 \times 1 \times 1 \mathrm{~cm}$ ocorriam distribuídos no lobo direito do fígado do Bovino 2. Essas áreas de infarto eram firmes, brancacentas e entremeadas por hemorragia (Fig.14). Petéquias e sufusões eram observadas na serosa e mucosa da vesícula biliar de todos os bovinos afetados. Em três bovinos, grandes hematomas distendiam o tecido perirrenal e ligamento do cólon descendente.

Com exceção do Bovino 2, todos os outros bovinos afetados mostravam hemorragias cardíacas; quando o coração era examinado desde a superfície pericárdica percebiam-se numerosos focos hemorrágicos de aproximadamente $0,5 \mathrm{~cm}$ de diâmetro que se aprofundam no miocárdio; quando o coração era examinado desde a superfície endocárdica, focos hemorrágicos subepicárdicos semelhantes podiam ser observados quase que exclusivamente no ventrículo direito.

Em três bovinos com lesões laringo-faríngeas ocorriam hemorragias próximas à entrada das criptas das tonsilas, que apareciam distendidas por edema e hemorragia. Em geral, os linfonodos estavam tumefeitos e com superfície de corte vermelha e úmida. Hematomas ocorriam ao redor dos linfonodos mesentéricos e hepáticos, mas essas hemorragias, em geral, não se estendem para o interior dos linfonodos, com exceção dos linfonodos renais que apresentavam focos de hemorragia de $0,2-0,5 \mathrm{~mm}$ de diâmetro na superfície de corte. Focos hemorrágicos de cerca de $2-3 \mathrm{~cm}$ de diâmetro com bordas irregulares eram observados na cápsula do baço. Numerosas petéquias e sufusões ocorriam distribuídas pelo timo.

Alterações no sistema respiratório ocorreram nos Bovinos 1-3. No primeiro havia grande número de petéquias e sufusões na pleura parietal e múltiplos lóbulos hemorrágicos apreciam na porção dorsal do lobo pulmonar diafragmático direito (Fig.9). Na traquéia e brônquios principais dos Bovinos 1 e 2 havia abundante espuma branca (edema) e petéquias e sufusões eram observadas na mucosa da traquéia. No Bovino 3 observaram-se coágulos de sangue nos seios nasais e nos cornetos (Fig. 15).

Hemorragias eram observadas nos cálices renais dos quatro bovinos afetados; essas hemorragias se estendiam até os ureteres de três bovinos que mucosa ureteral enegrecida por hemorragia que se estendia pelos ureteres (Fig.16) desde os cálices renais até próximo o óstio vesical. $\mathrm{Na}$ bexiga dos quatro bovinos afetados havia 100-200ml de urina com sangue (Fig.17) e observam-se hemorragia e edema difusos e acentuados que se estendiam da mucosa até a serosa causando espessamento da parede vesical (Fig.18) e, em alguns pontos, se difundiam até os tecidos retroperitoneais adjacentes.

Nos três bovinos em que os testículos foram examinados havia petéquias e pequenas sufusões no mesórquio e na túnica vaginal ao longo do epidídimo; hemorragias multifocais de $0,5 \mathrm{~cm}$ de diâmetro podiam ser observadas na superfície de corte dos testículos (Fig.19) e eram distribuídas por todo o parênquima testicular.

As grandes massas musculares dos membros pélvicos estavam pálidas e continham múltiplas petéquias e sufusões. Um hematoma de $10 \times 3 \times 1 \mathrm{~cm}$ é observado no perimísio do músculo serrato maior de um dos bovinos. Hemartrose acentuada (Fig.20) foi observada nas articulações dos membros pélvicos nos quatro bovinos afetados. Petéquias foram observadas nas adrenais de dois bovinos afetados.

Nenhuma alteração de necropsia que pudesse ser relacionada com os efeitos da intoxicação foi observada no bovino controle que foi submetido à eutanásia e necropsiado ao final do experimento.

\section{Achados histopatológicos}

As alterações hemorrágicas observadas na necropsia foram confirmadas no exame histológico nos quatro bovinos. A distribuição e intensidade das lesões corresponderam respectivamente aos achados macroscópicos (Quadro 6). As hemorragias nos intestinos delgado e grosso eram mais acentuadas na camada serosa e se estendiam até a mucosa nos casos mais graves. Na mucosa as lesões eram mais proeminentes ocorriam em locais com placas de Peyer, onde comumente eram observados perda de vilosidades intestinais com intensa quantidade de células sanguíneas e fibrina (coágulos sanguíneos) e agregados bacterianos. Em meio a essas áreas era observado intenso infiltrado linfoplasmocitário e neutrofílico. Na submucosa dessas regiões havia ainda congestão vascular

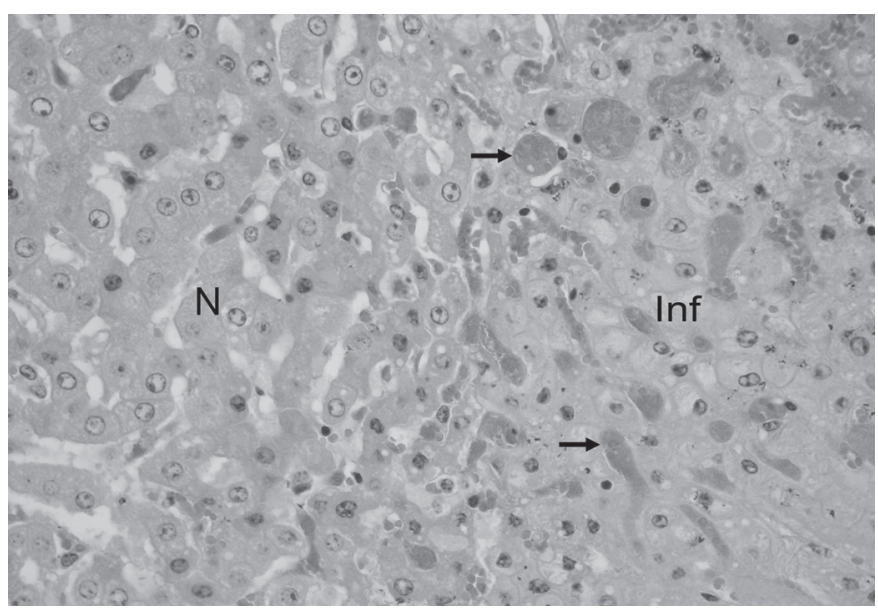

Fig.21. Histopatologia do infarto no fígado do Bovino 2 na intoxicação experimental aguda por Pteridium aquilinum. Observa-se área de parênquima normal $(\mathrm{N})$ separada de área de necrose de coagulação (Inf). Na zona de interface entre as duas áreas há miríades de bactérias (setas). HE, obj.40x. 


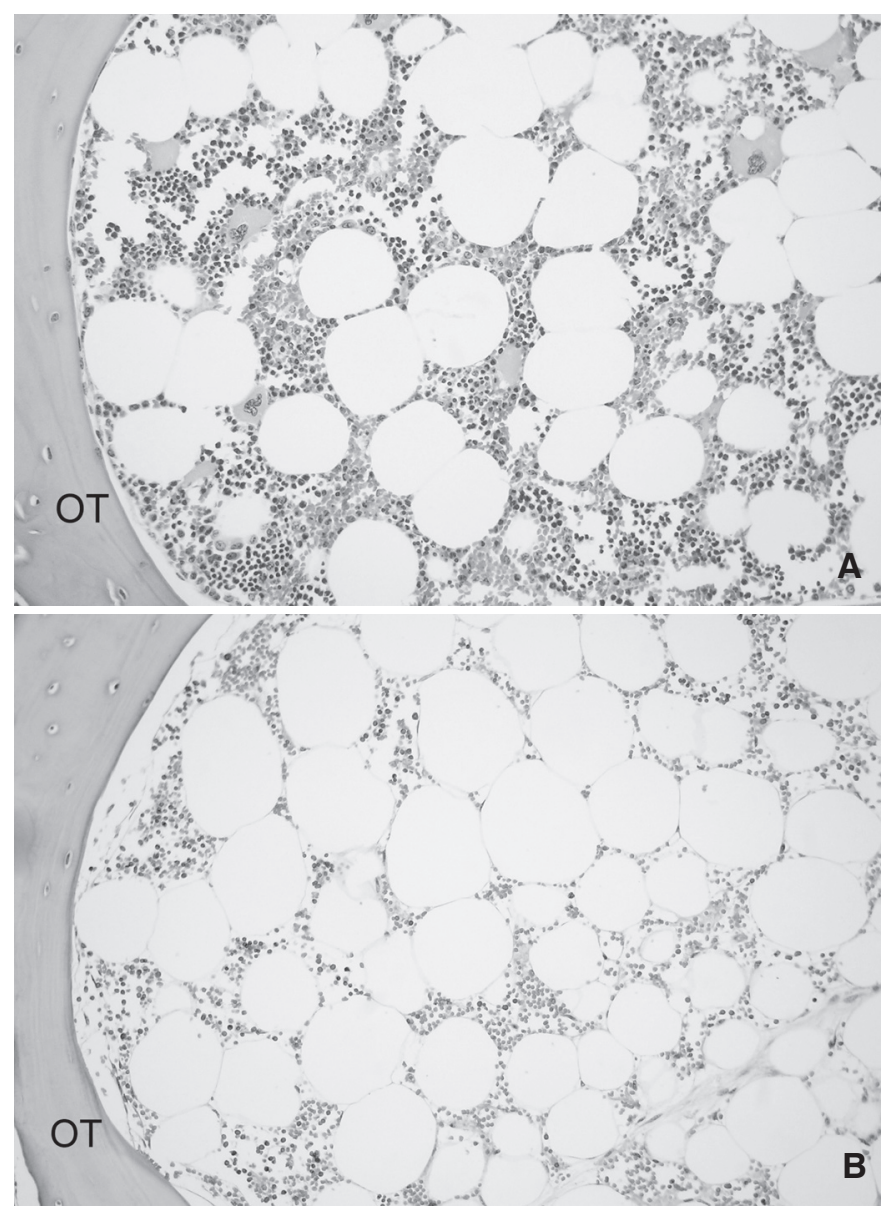

Fig.22. Histopatologia da medula óssea de dois bovinos utilizados no experimento de intoxicação experimental aguda por Pteridium aquilinum. OT = osso trabecular. HE, obj.20x. (A) Bovino 5 (controle) mostrando medula óssea normal. (B) Bovino 3 mostrando acentuada aplasia de medula óssea.

com tumefação de células endoteliais, hemorragia perivascular e edema acentuado do interstício e de camadas musculares adjacentes. No Bovino 4 eram observadas inúmeras hifas dicotômicas em meio à fibrina e invadindo a parede vascular. Alguns vasos eram totalmente obliterados por exemplares fúngicos PAS-positivos e trombos. As úlceras de abomaso observadas no Bovino 3 atingiam a submucosa que apresentava congestão e hemorragia perivascular. O fígado dos Bovinos 1 e 2 mostraram áreas de hemorragias subcapsulares e congestão leve dos sinusóides hepáticos. As áreas de infarto, vistas na necropsia, eram caracterizadas por áreas de necrose de coagulação aguda multifocais a coalescente aleatórias (Fig.21). Trombos sépticos com quantidades massivas de agregados bacterianos, predominantemente obliteravam artérias e arteríolas periportais e inúmeros sinusóides em direção as veias centrolobulares. Os Bovinos 3 e 4 demonstraram apenas áreas hemorrágicas subcapsulares. Hemorragias leves a acentuadas e edema eram observados em toda a parede da vesícula biliar dos quatro bovinos; nos Bovinos 2 e 4 as lesões eram acentuadas. Congestão moderada dos vasos sanguíneos do parênquima renal e dos glomérulos foi observada nos quatro bovinos. Hemorragias perivasculares e edema na região da pelve renal variaram de leve a moderada. O Bovino 2 exibiu trombos séptico na região medular do rim. No encéfalo, observaram-se edema moderado e leves hemorragias nos vasos das leptomeninges e do neurópilo. Verificaram-se hemorragias no parênquima e superfície capsular das adrenais, baço, medula espinhal e pulmão. Nos quatro bovinos era observada acentuada aplasia de medula óssea com marcada perda da série granulocítica e eritrocítica e ausência de megacariócitos (Fig.22). Com a perda dessas células os adipócitos tornavam-se mais evidentes e os eritrócitos distendiam os sinusóides.

\section{DISCUSSÃO}

Os bovinos deste experimento demonstraram-se susceptíveis ao efeito tóxico da planta, desenvolvendo sinais clínicos e achados patológicos característicos da doença (Osebold 1951, Sippel 1952, Evans et al. 1954, Tustin et al. 1968, Naftalin \& Cushnie 1954, Anjos et al. 2008). Experimentos anteriores revelaram que em casos agudos da intoxicação por Pteridium aquilinum os bovinos que ingerem doses diárias da planta superiores a $10 \mathrm{~g} / \mathrm{kg}$ do peso corpóreo ou totalizando em média o valor do seu peso corporal, desenvolvem a forma aguda (Kitahara 1974). Neste experimento, a maior quantidade de planta ingerida correspondeu a $63,3 \%$ do peso do bovino e as doses médias diárias variaram de 8 a 10,5g/kg por até 58 dias.

É descrito que o princípio ativo (ptaquilosídeo) presente em $P$. aquilinum tem ação radiomimética que medeia a aplasia progressiva da medula óssea e a síndrome hemorrágica associadas à intoxicação aguda em bovinos (Fenwick 1988, Hirono et al. 1984). A lesão aplásica da medula óssea é semelhante às observadas em casos de anemia aplásica por irradiação (Young 2002). Nestes casos, o agente patogênico promove distúrbios de expressão antigênica e genéticos nas células-tronco e célulastronco pluripotentes da medula óssea, que passam a expressar moléculas de superfície que induzem uma resposta imune, na qual, linfócitos T produzem citocinas que inibem sua proliferação e diferenciação em células mielóides. Acredita-se ainda que as alterações genéticas sofridas por essas células também inibem sua diferenciação (Young 2002, Brodsky \& Jones 2005). Além disso, a radiação pode causar danos permanentes na parede dos vasos sanguíneos com aumento da permeabilidade vascular para moléculas maiores que intensificam o quadro hemorrágico (Evans 1968, Fenwick 1988).

Com base no fato de que alguns bovinos intoxicados espontaneamente por samambaia apresentam hemorragias na forma de equimoses, hematomas e derrame cavitário hemorrágico, foi aventada a hipótese de que, além da já conhecida patogênese que tem como base a trombocitopenia, algum distúrbio na hemostasia secundária pudesse estar envolvido nesse processo (Anjos et al. 2008). Baseado nisso, foi realizada a determinação 
dos tempos de coagulação (TP e TPPA). Os resultados por nós encontrados demonstram que: 1) não houve prolongamento nos tempos de coagulação (TP e TPPA) (Bov.1), 2) houve prolongamento no TTPA, mas que não ultrapassou o limite fisiológico descrito para espécie (Bov.3), 3) houve prolongamento no TTPA que ultrapassou o limite fisiológico, mas esses valores eram semeIhantes aos vistos em outro bovino (Bov.1) antes da ingestão da planta, e 4) houve prolongamento no TP (Bov.2 e 4), entretanto, nesses dois casos, os valores estiveram próximos ao limite fisiológico máximo descrito para espécie. Assim, na nossa interpretação, as variações nos tempos de coagulação não são significativas e excluem a possibilidade de alteração da hemostasia secundária na patogênese dessa intoxicação. A determinação dos PDF na circulação dos bovinos foi realizada na busca de subsídios que permitissem confirmar ou refutar a possibilidade de ocorrência de coagulação intravascular disseminada (CID). Entretanto, como a partir dos 45 dias todos os bovinos, incluindo o bovino controle, apresentaram níveis detectáveis de PDF na circulação, esses resultados foram invalidados. Com base nesse aspecto não foi possível determinar a ocorrência ou não de CID, entretanto, com base nos achados referentes aos tempos de coagulação, pode-se afirmar que tal fenômeno não ocorreu em nenhum dos bovinos deste experimento.

É possível que a ocorrência de um padrão hemorrágico não puramente típico de distúrbio da hemostasia primária, ou seja, não observado apenas como petéquias, sufusões e víbices, mas sim uma associação dessas lesões com equimoses, hematomas e acúmulo de sangue intracavitário, ocorra apenas pela trombocitopenia. Nesse caso, isso poderia ser explicado pela falta da plaqueta como base de nucleação dos fatores de coagulação. É sabido que a exposição da fosfatidilserina, um fosfolipídio da camada interna da membrana plaquetária, é fundamental na coagulação, pois é sobre essa superfície plaquetária que irá ocorrer a ativação do fator $X$ e da protrombina através da formação dos complexos tenase e protrombinase. Dessa forma, a ausência das plaquetas, em decorrência da trombocitopenia induzida pela planta, causaria não só o já conhecido déficit na hemostasia primária, mas também déficit na hemostasia secundária, o que explicaria a ocorrência desse padrão hemorrágico misto, mesmo com tempos de coagulação normais, pois tais tempos são determinados in vitro e, consequentemente, seus resultados laboratoriais independem do número de plaquetas apresentado pelo indivíduo no momento da coleta do sangue.

Os achados hematológicos mais importantes observados nos bovinos deste estudo foram leucopenia por neutropenia e trombocitopenia. Diminuição nos valores absolutos de neutrófilos e plaquetas já podia ser vista 30 dias AIP, entretanto, nesse momento do experimento, apenas um bovino era neutropênico e nenhuma era trombocitopênico. Aos 53 dias todos os bovinos podiam ser considerados marcadamente neutropênicos e trombocitopênicos. Diferentemente desses achados, apenas dois dos quatro bovinos tornaram-se anêmicos. Além disso, a anemia vista nesses dois bovinos era leve, ao contrário da neutropenia e da trombocitopenia, que era acentuada. Acreditamos que esses achados hematológicos possam ser explicados pela vida média de cada uma das células envolvidas. Plaquetas e eritrócitos de bovinos têm vida média de 5-10 dias e 157-162 dias, respectivamente. Embora a literatura consultada não descreva a vida média dos neutrófilos de bovinos, a vida média dessas células em cães, eqüinos e humanos é de 5,5-7,6 horas, 10,5 horas e 7-14 horas, respectivamente. Dessa forma, quando a medula óssea deixa de produzir os elementos figurados do sangue em decorrência de alguma agressão aguda, a diminuição ocorrerá de acordo com a vida média de cada célula. Assim, na aplasia medular aguda, independentemente da causa ou da espécie afetada, neutropenia será notada um pouco antes de trombocitopenia e ambas ocorrerão muito antes da anemia. Além disso, como a vida média dos eritrócitos de mamíferos é muito longa, é bem provável que a morte do indivíduo ocorra antes de estabelecer-se um quando anêmico em decorrência da insuficiente produção dos eritrócitos (Fighera 2001). Obviamente, as hemorragias decorrentes da trombocitopenia farão o indivíduo perder sangue e, consequentemente, tornar-se anêmico, mas, nesse caso, a anemia decorre muito mais da perda dos eritrócitos do que da falha na sua produção. Essa hipótese já havia sido levantada por outro autor (Valli 1994) e pôde ser comprovado neste estudo, pois embora todos os quatro bovinos intoxicados tenham demonstrado claras evidências hematológicas de aplasia medular, vista como neutropenia e trombocitopenia marcada, apenas dois demonstraram anemia leve.

A determinação da atividade sérica das enzimas AST, GGT e FA e a mensuração da uréia e da creatinina, realizadas com a finalidade de avaliar o comportamento bioquímico hepático e renal frente a um possível quadro de CID, demonstraram apenas alterações relacionadas com o metabolismo protéico e com lesão hepática primária. Todos os bovinos afetados apresentaram aumento da uréia não associado à alteração dos níveis de creatinina, ou seja, aumento da uréia de origem não renal. Isso provavelmente se deva a um aumento na absorção de proteínas decorrente da hemorragia intestinal, pois é sabido que animais e humanos com doença intestinal hemorrágica desenvolvem aumento nos níveis de uréia por esse mecanismo. O aumento na atividade sérica das enzimas AST e GGT que ocorreu no Bovino 2 é provavelmente decorrente da necrose associada à presença de colônias bacterianas que embolizaram para o fígado. $\mathrm{O}$ motivo pelo qual o Bovino 1, que também apresentou necrose hepática secundária à embolização bacteriana, não desenvolveu manifestação bioquímica da mesma forma que o Bovino 2 não pôde ser estabelecido. Também não pôde ser explicado o motivo pelo qual o Bovino 3 demonstrou aumento na atividade sérica da GGT. 
Os isolados bacterianos apresentados neste estudo são descritos como importantes agentes em doenças septicêmicas tanto em animais domésticos como em humanos (Biberstein et al. 1984, Angus et al. 2001). É possível que complicações septicêmicas tenham participação na morte de bovinos intoxicados com $P$. aquilinum.

É interessante ressaltar duas manifestações clinicopatológicas apresentadas pelos bovinos deste experimento. A primeira delas é a hematúria. Hematúria é geralmente associada a tumores vesicais na à intoxicação crônica por samambaia (Tokarnia et al. 1969, Souto et al 2006b). No entanto, lesões hemorrágicas de bexiga podem também produzir hematúria na intoxicação aguda, como foi verificado nos quatro bovinos deste estudo e como já tinha sido descrito na literatura associados a casos espontâneos de intoxicação aguda por samambaia em bovinos (Bosshart \& Hagan 1920, Glesson 1944). A segunda é a manifestação da forma laríngea. Dois tipos de manifestação clínica têm sido observados na intoxicação aguda por samambaia em bovinos (Fletcher 1944, Sippel 1952): 1) o tipo entérico, que é o mais freqüente, caracteriza-se principalmente por sinais clínicos de depressão, perda de apetite, temperaturas elevadas e pulso fraco. São encontrados ainda, enterite, com coágulos de sangue e cheiro pútrido nas fezes, palidez da conjuntiva e sangramento das membranas mucosas dos olhos, nariz, vagina e ânus; e 2) o tipo laríngeo, em que os sinais clínicos incluem febre alta, ronco, dificuldade de respirar e edema de laringe. O tipo laríngeo ainda não havia sido descrito em associação à intoxicação aguda por samambaia em bovinos no Brasil. No entanto, achamos que esse sinal clínico caracterizado por ronco e dispnéia deve ser considerado como indicativo no diagnóstico da intoxicação aguda por samambaia em bovinos, mas é arbitrário dividir a doença em duas formas ou dois tipos, pois os sinais clínicos se sobrepõem.

\section{REFERÊNCIAS}

Angus D.C., Linde-Zwirble W.T., Lidicker J., Clermont G., Carcillo J. \& Pinsky M.R. 2001 Epidemiology of severe sepsis in the United States: Analysis of incidence, outcome, and associated costs of care. Crit. Care Med. 29:1303-1310.

Anjos B.L., Irigoyen L.F., Fighera R.A., Gomes A.D., Kommers G.D. \& Barros C.S.L. 2008. Intoxicação aguda por samambaia (Pteridium aquilinum) em bovinos na Região Central do Rio Grande do Sul. Pesq. Vet. Bras. 28:501-507.

Biberstein E.L., Jang S.S. \& Hirsh D.C. 1984. Species distribution of coagulase-Positive staphylococci in animals. J. Clin. Microbiol. 19: 610-615.
Bosshart J.K. \& Hagan W.A. 1920. A fatal unindefied disease of cattle in New York State. Cornell Vet. 10:102-13.

Brodsky R.A. \& Jones R.J. 2005. Aplastic anemia. Lancet 365:16471656.

Evans W.C., Evans E.T. \& Hughes L.E. 1954. Studies on bracken fern in cattle. Part I. Brit. Vet. J. 110:295-306.

Evans I.A. 1968. The radiomimetic nature of bracken toxin. Cancer Res. 28:2252- 2261.

Fenwick G.R. 1988. Bracken (Pteridium aquilinum): Toxin effects and toxic constituents. J. Sci. Food Agric. 46:147-173.

Gleeson L. 1944. Suspected bracken poisoning. Vet. Rec. 56:374.

Fighera R.A. 2001. Anemia em Medicina Veterinária. Santa Maria. O autor. 214p.

Fletcher J. 1944. Bracken poisoning in cattle. Vet. Rec. 56:478.

Hirono I., Kono Y., Takahashi K., Yamada K., Niwa H., Ojika M., Kigoshi H., Nuyama K. \& Uosaki Y. 1984. Reproduction of acute bracken poisoning in a calf with ptaquiloside, a bracken constituent. Vet. Rec. 115(15):375-378.

Kitahara T. 1974. Experimental studies on bracken fern poisoning in cattle. Bulletin of the Nippon Veterinary and Zootechnical College 23:88107. [Abstract, Vet. Bull.]

Naftalin J.M. \& Cushnie G.H. 1954. The experimental bracken fern poisoning in calves.

Osebold J.W. 1951. An approach to the pathogenesis of fern poisoning in the bovine species. J. Am. Vet. Med. Assoc. 121:440-441.

Rissi D.R., Rech R.R., Pierezan F., Gabriel A.L., Trost M.E., Brum J.S., Kommers G.D. \& Barros C.S.L. 2007. Intoxicação por plantas e micotoxinas associadas a plantas em bovinos no Rio Grande do Sul. Pesq. Vet. Bras. 27:261-268.

Sippel W.L. 1952. Bracken fern poisoning. J. Am. Vet. Med. Assoc. 121:9-13.

Souto M.A.M., Kommers G.D., Barros C.S.L., Piazer J.V.M., Rech R.R., Riet-Correa F. \& Schild A.L. 2006a. Neoplasias do trato alimentar superior de bovinos associadas ao consumo espontâneo de samambaia (Pteridium aquilinum). Pesq. Vet. Bras. 26:112-122

Souto M.A.M., Kommers G.D., Barros C.S.L., Rech R.R. \& Piazer J.V.M., 2006b. Neoplasmas da bexiga associados à hematúria enzoótica bovina. Ciência Rural 36:1647-1650.

Tokarnia C.H., Döbereiner J. \& Canella C.F.C. 1967. Ocorrência da intoxicação aguda por samambaia (Pteridium aquilinum (L.) Kuhn) em bovinos no Brasil. Pesq. Agropec. Bras. 2:329-336.

Tokarnia C.H., Döbereiner J. \& Canella C.F.C. 1969. Ocorrência de hematúria enzoótica e de carcinomas epidermóides no trato digestivo superior em bovinos no Brasil. Part I. Estudos complementares. Pesq. Agropec. Bras. 4:209-224.

Tustin R.C., Adelaar T.T. \& Medal-Johnsen C.M. 1968. Bracken fern poisoning in cattle in Natal Midlands. J. S. Afr. Vet. Med. Assoc. 39(3):91-99

Valli V.E.O. 2007. Hematopoietic system, p.107-324. In: Maxie M.G. (Ed.), Jubb, Kennedy and Palmer's Pathology of Domestic Animals. Vol.3. 5th ed. Elsevier, Philadelphia.737p.

Young N.S. 2002. Acquired aplastic anemia. Ann. Intern. Med.136:534546. 